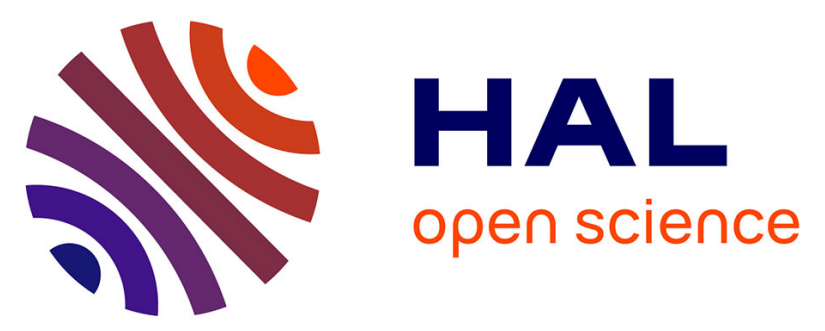

\title{
The novelty of phytofurans, isofurans, dihomo-isofurans and neurofurans: Discovery, synthesis and potential application
}

Claire Cuyamendous, Aurélien de La Torre, Yiu Yiu Lee, Kin Sum Leung, Alexandre Guy, Valérie Bultel-Poncé, Jean-Marie Galano, Jetty Chung-Yung Lee, Camille Oger, Thierry Durand

\section{To cite this version:}

Claire Cuyamendous, Aurélien de La Torre, Yiu Yiu Lee, Kin Sum Leung, Alexandre Guy, et al.. The novelty of phytofurans, isofurans, dihomo-isofurans and neurofurans: Discovery, synthesis and potential application. Biochimie, 2016, pp.49-62. 10.1016/j.biochi.2016.08.002 . hal-02593271

\section{HAL Id: hal-02593271 \\ https://hal.science/hal-02593271}

Submitted on 15 May 2020

HAL is a multi-disciplinary open access archive for the deposit and dissemination of scientific research documents, whether they are published or not. The documents may come from teaching and research institutions in France or abroad, or from public or private research centers.
L'archive ouverte pluridisciplinaire HAL, est destinée au dépôt et à la diffusion de documents scientifiques de niveau recherche, publiés ou non, émanant des établissements d'enseignement et de recherche français ou étrangers, des laboratoires publics ou privés. 
Review

\title{
The novelty of phytofurans, isofurans, dihomo-isofurans and neurofurans: Discovery, synthesis and potential application
}

\author{
Claire Cuyamendous ${ }^{\mathrm{a}}$, Aurélien de la Torre ${ }^{\mathrm{a}}$, Yiu Yiu Lee ${ }^{\mathrm{b}}$, Kin Sum Leung ${ }^{\mathrm{b}}$, \\ Alexandre Guy ${ }^{\mathrm{a}}$, Valérie Bultel-Poncé ${ }^{\mathrm{a}}$, Jean-Marie Galano ${ }^{\mathrm{a}}$, Jetty Chung-Yung Lee ${ }^{\mathrm{b}}$, \\ Camille Oger ${ }^{\mathrm{a}}$, Thierry Durand ${ }^{\mathrm{a}, *}$ \\ a Institut des Biomolécules Max Mousseron, UMR 5247 CNRS, Université de Montpellier, ENSCM, Faculté de Pharmacie de Montpellier, 15 Avenue Charles \\ Flahault, Bâtiment D, 34093, Montpellier Cedex 05, France \\ b School of Biological Sciences, The University of Hong Kong, Pokfulam Road, Hong Kong Special Administrative Region
}

\section{A R T I C L E I N F O}

\section{Article history:}

Received 20 May 2016

Accepted 7 August 2016

Available online 9 August 2016

\section{Keywords:}

Polyunsaturated fatty acids

Isofurans

Dihomo-isofurans

Phytofurans

Neurofurans

Biomarkers

\begin{abstract}
A B S T R A C T
Polyunsaturated fatty acids (PUFA) are oxidized in vivo under oxidative stress through free radical pathway and release cyclic oxygenated metabolites, which are commonly classified as isoprostanes and isofurans. The discovery of isoprostanes goes back twenty-five years compared to fifteen years for isofurans, and great many are discovered. The biosynthesis, the nomenclature, the chemical synthesis of furanoids from $\alpha$-linolenic acid (ALA, C18:3 n-3), arachidonic acid (AA, C20:4 n-6), adrenic acid (AdA, 22:4 n-6) and docosahexaenoic acid (DHA, 22:6 n-3) as well as their identification and implication in biological systems are highlighted in this review.
\end{abstract}

\section{Contents}

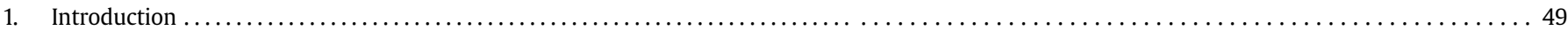

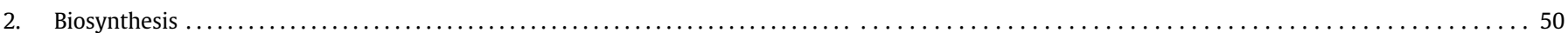

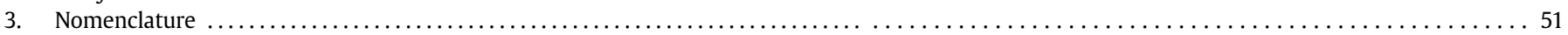

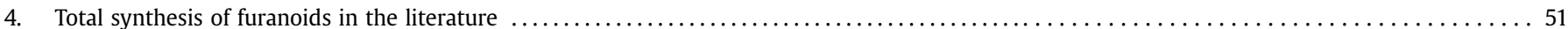

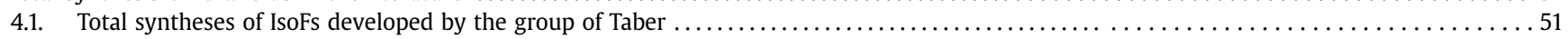

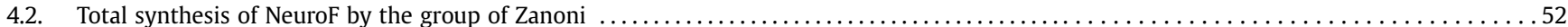

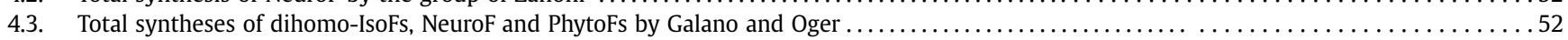

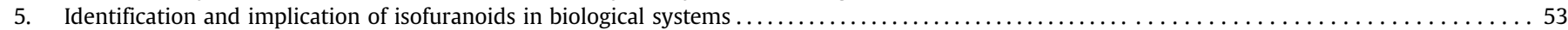

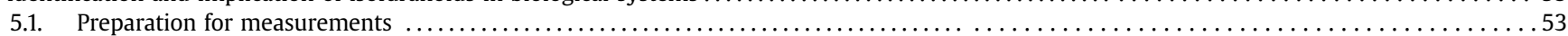

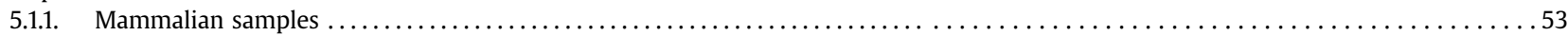

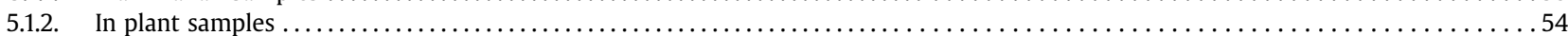

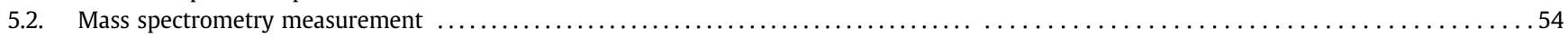

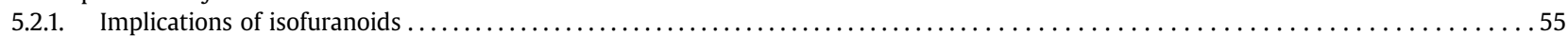

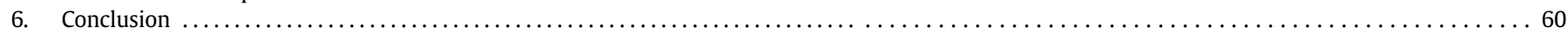

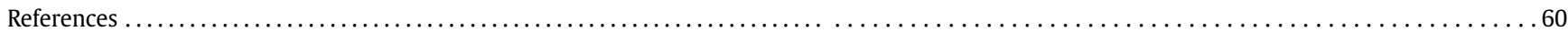

\footnotetext{
* Corresponding author.

E-mail address: thierry.durand@umontpellier.fr (T. Durand).
}

\section{Introduction}

Reactive oxygen species (ROS) are free radicals generated under physiological conditions, but also under the so-called oxidative 
stress condition (OS) when natural antioxidant defences are overwhelmed by the amount of ROS generated. ROS target oxidation prone polyunsaturated fatty acids (PUFA) to undergo lipid peroxidation (LPO) [1]. The hydroxyl radical $(\cdot \mathrm{OH})$ is believed to be the most reactive radical in vivo, however other radicals can also participate in the processes of LPO [2]. However, no contentious exists if ROS can be specific of certain lipid and therefore of certain type of oxygenated metabolites. Furthermore, it is also believed that the non-enzymatic free radical mechanism of LPO that occurs in three phases (initiation, propagation, termination) could be more subtle than anticipated $[3,4]$. OS and LPO have been clearly associated to several pathologies and diseases, and one particular biomarker of OS was discovered in the nineties and called $\mathrm{F}_{2}$-isoprostanes $\left(\mathrm{F}_{2}\right.$-IsoPs). They are generated from autooxidation of arachidonic acid bounded phospholipid (AA, C20:4 n-6) and are circulating in biological fluids as free form mainly. Today they are currently considered as the best marker of OS in biological systems. In the biosynthesis route of IsoPs, an endoperoxide carbon radical (B) undergoes a 5-exo-trig cyclization to form the cyclopentane ring of IsoPs $[5,6]$ (Scheme 1). However, at high oxygen tension further transformations can occur and oxygen molecule may react with the endoperoxyde carbon radical to generated tetrahydrofuran ring containing compounds. Those new metabolites were termed isofurans (IsoFs). This second route may prevent the IsoPs pathway and limit their formation [7]. It is thus reasonable to measure IsoFs in addition to IsoPs in the case of high oxygen tension injury e.g. hyperoxia, ischemia-reperfusion etc. Depending on the parent PUFA that at least would possess two skipped diene units (i.e; three alkenes separated by a $\mathrm{CH}_{2}$ ), other furanoid metabolites can be formed and were discovered in human tissues or fluids e.g. neurofurans (NeuroFs) from docosahexaenoic acid (DHA, 22:6 n-3), dihomo-isofurans (dihomo-IsoFs) from adrenic acid (AdA) and in plants like the phytofurans (PhytoFs) from $\alpha$-linolenic acid (ALA, C18:3 n-3). Those metabolites should be added to the list of metabolites to quantitate OS. The present review aims to provide a concise overview on these furanic PUFA metabolites, from how they are formed in vivo and how they are named. We also would like to highlight that these metabolites are not commercially available and need to be prepared by organic chemists before being evaluated. Accordingly, the syntheses developed until now will be presented. Finally, the last part will be focused on the identification of those metabolites and their implication in biological systems. More importantly, this review will also give keys to the researchers in the preparation of the samples and the measurements of such metabolites.

\section{Biosynthesis}

In 1990, Morrow and co-workers revealed the formation of IsoPs from arachidonic acid esterified as phospholipid, and explained their formation via a radical initiated mechanism [5]. Hydrogen abstraction of the bis-allylic hydrogen atom of AA ester lead to

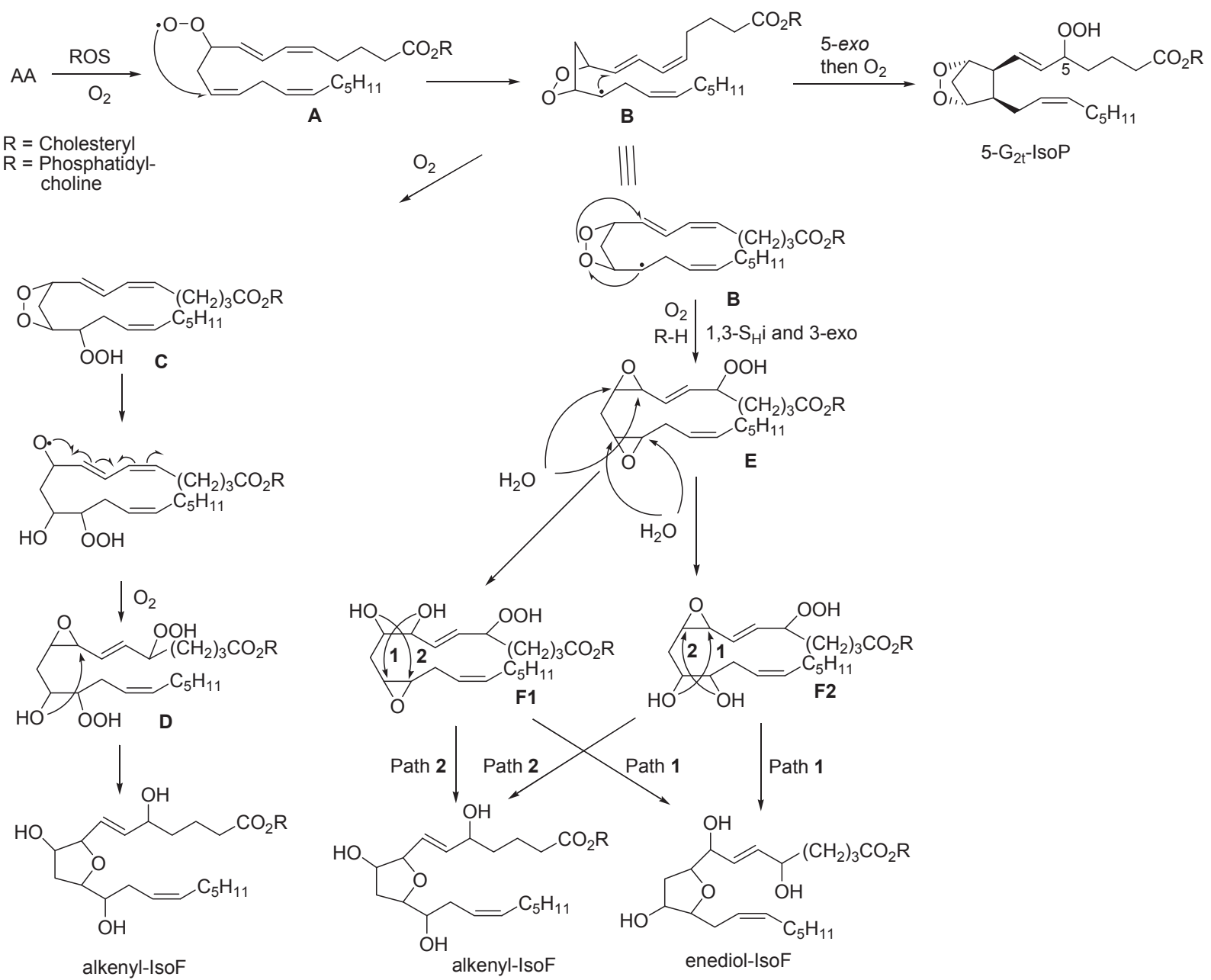

Scheme 1. Mechanistic explanation for the formation of IsoPs and IsoFs (only one isomer of one series is shown). 
isomeric pentadienyl radicals which are oxygenated into pentadienylperoxyl radicals (A) (Scheme 1). Peroxyl radicals A can also undergo kinetically controlled 5-exo cyclization with suitably positioned alkene units to generate the endoperoxide intermediate B (dioxolanylcarbinyl radical). Irreversible carbon-centered radical intramolecular attack onto a double bond generates the cyclopentane ring with the appropriate configuration (cis) characteristic of the IsoPs.

However, another fate of dioxolanylcarbinyl radical B was revealed by Fessel and coworkers in 2002. It relies on the diradical character of $\mathrm{O}_{2}$ and its high reactivity toward carbon-centered radicals, and permits to access IsoFs [7]. Interestingly, early in vitro experiment revealed the importance of oxygen concentration on the preferential generation of IsoFs versus IsoPs, and while the IsoPs concentration reached a plateau at $21 \%$ oxygen, the concentration of IsoFs increased further as the oxygen tension increased. This observation also proved to be true for organs of known different oxygen tension like liver versus lung.

The mechanism of formation was closely investigated and so far three biosynthetic pathways are proposed for the formation of IsoFs. From those and by competitive pathways, two types of IsoFs are synthesized, namely the alkenyl-IsoFs and the enediol-IsoFs, each of them present as a mixture of five regioisomeris and diastereomers. As shown in Scheme 1, we represented two out of the three biosynthetic pathways which all agree with the in vitro isotopic labelling experiments [6].

It is believed that these pathways diverge from dioxolanylcarbinyl radical $\mathbf{B}$. In the first one, oxygen trapping can lead to hydroperoxy-1,2-dioxolane $\mathbf{C}$ (Scheme 1, bottom left), which undergoes after single electron reduction of the peroxide bridge, 3exo cyclization and oxygen trapping, the dihydroperoxy epoxide D. Further regioselective intramolecular nucleophilic ring opening of the epoxide by the hydroxyl group and final reduction of the hydroperoxide gives rise to the four regioisomeric alkenyl isofuran classes as mixture of diastereomers.

Another route (Scheme 1, bottom right) is also possible directly from dioxolanylcarbinyl radical $\mathbf{B}$ after a facile $1,3-\mathrm{S}_{\mathrm{H}} \mathrm{i}$ reaction, 3exo cyclization and oxygenation to lead diepoxyhydroperoxide $\mathbf{E}$. After hydrolysis to form the regioisomeric epoxy diols F1 and F2, intramolecular nucleophilic ring opening of the epoxide by a suitably positioned hydroxy group leads to alkenyl-IsoFs according to path 1 and to enediol-IsoFs by path 2 .

After the initially discovered isofuranoid derived AA, analogous compounds from other PUFAs were discovered like the NeuroFs in 2008 by FitzGerald [8] from DHA, as depicted in Table 1. Later, the combined groups of Galano/Durand and Lee discovered the dihomo-IsoFs derived from AdA in pig brain [9]. Recently, this join collaborative effort also identified the PhytoFs from ALA identified in seed and nuts [10]. It is obvious that other isofuranoids are probably generated from other PUFA and are still to be discovered.

\section{Nomenclature}

Biosynthetically related to IsoPs and containing a furan ring, those metabolites were naturally labeled as IsoFs. As depicted in the biosynthesis part, IsoFs are produced by three different pathways, and lead to the formation of two classes of IsoFs, called alkenyl and enediol. There are thus eight different isofuran regioisomers (four alkenyl and four enediol), which can exist as 16 diastereomers, for a total of 256 enantiomerically-pure metabolites. A systematic nomenclature allows the differentiation of each isomeric structures and established by Taber, Fessel and Roberts [11]. This nomenclature is based on the relative orientation of the side chains and substituents. Furthermore, this nomenclature system was validated by IUPAC.

Several rules must be followed for the generation of a name from a structure (Fig. 1). First, it is noted that: the carbon number one is the carbon atom of the acid function $(\mathrm{COOH})$ and the first ring carbon atom as well as the carbon bearing the hydroxyl groups $(\mathrm{OH})$ on the side chain have, by default, $(S)$ configuration. Secondly, the relative orientation of the alkyl chains must be defined: syn $(\mathrm{S})$ or anti (A), prior to the relative orientation of the ring hydroxyl group and the adjacent alkyl chain: cis $(\mathrm{C})$ or trans $(\mathrm{T})$. Then, the carbon number of the $E$ double bond should be addressed as a superscript after the $\Delta$ sign, followed by the carbon number of the first ring carbon atom. The abbreviation IsoF, for isofuran, is appended thereafter and reveals the parent PUFA: IsoF (AA and EPA), PhytoF (ALA), dihomo-IsoF (AdA) and NeuroF (DHA).

Great care should be paid to the configuration of the first ring carbon atom and the carbon atoms bearing hydroxyl groups on the side chain $((S)$ by default). If the configuration of the hydroxyl is inverted, the carbon number followed by "epi" is used as a prefix. If the first ring carbon atom configuration is reversed, the prefix "ent" is used and all the hydroxyl groups on the side chains are considered $(R)$ as default.

\section{Total synthesis of furanoids in the literature}

The total synthesis of furanoid PUFA metabolites is of great interest because little is known about their biochemistry. Thus, four synthetic strategies were developed by organic chemists. The first one was described by Taber et al. in 2004 through a diol epoxide benzenesulfonate cyclization and permits the synthesis of AA derived IsoFs both alkenyl and enediol type [12-14]. More recently, Zanoni's group used Trost asymmetric alkylation for the first synthesis of a neurofuran [15]. Finally, the Galano and Oger group developed in parallel two strategies toward furanoid derivatives based on Borhan cyclization or a one-pot Payne rearrangement/5exo-tet cylisation, giving access to enediol and alkenyl furanoids derived from ALA, AdA and DHA $[9,10,16]$. So far, none of the isofuranoids synthesized are commercially available but can be available from the Zanoni and Galano/Oger/Durand teams (isofuranoids from Taber were kindly given to the Montpellier group).

\subsection{Total syntheses of IsoFs developed by the group of Taber}

The first strategy developed by Taber in 2004 gave access to the alkenyl furans and relied on an epoxide intermediate $\mathbf{1}$ where the lateral chains are introduced later on the synthesis (Scheme 2A) [12].

The epoxide moiety 1 comes from an epoxide opening cyclization where the benzenesulfonate unit is substituted (compound $\mathbf{2}$ ).

Table 1

Summary of the number of oxygenated furan metabolites of PUFAs generated.

\begin{tabular}{|c|c|c|c|c|}
\hline PUFA & Metabolite abbreviation & Number of lateral chain structures & Number of regioisomers & Number of isomers \\
\hline $\mathrm{AA}$ & IsoF & 4 & 8 & 256 \\
\hline AdA & Dihomo-IsoF & 4 & 8 & 256 \\
\hline ALA & PhytoF & 4 & 4 & 128 \\
\hline DHA & NeuroF & 8 & 16 & 512 \\
\hline
\end{tabular}




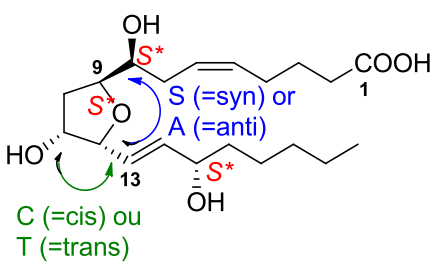

$A C-\Delta^{13}-9$-isoF

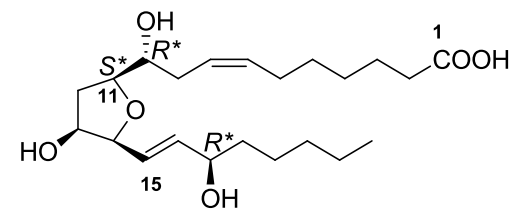

10,17-diepi-SC- $\Delta^{15}$-11-dihomo-IsoF

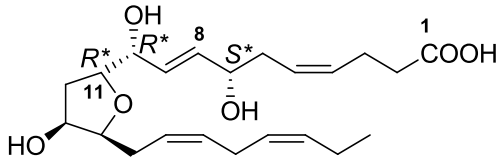

ent-7-epi-AC- $\Delta^{8}-11-$ NeuroF

Fig. 1. Nomenclature of the furan derived from PUFA.

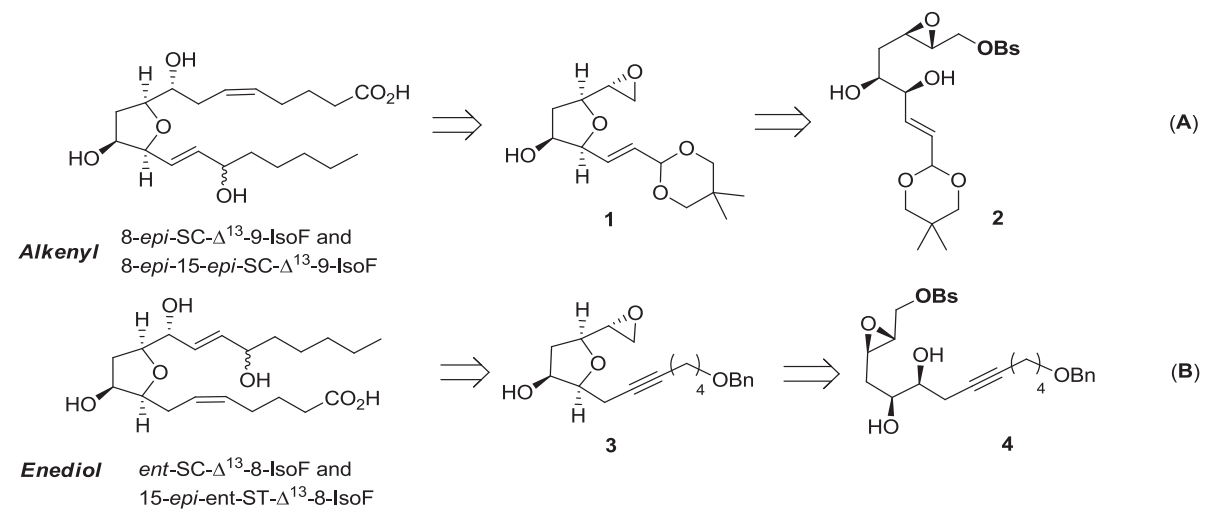

Scheme 2. Taber synthetic strategies.

Thanks to Sharpless epoxidation and dihydroxylation reactions, all stereogenic centers are controlled and may be changed by a simple modification of the chiral ligand. Moreover, even if the SC structure is obtained herein, a Mitsunobu reaction on epoxide $\mathbf{2}$ may allow the change of configuration of the hydroxyl group on the furan and thus the synthesis of ST structures. This strategy permitted the synthesis of the 8 -epi-SC- $\Delta^{13}-9$-IsoF and its epimers on the 15 th carbon atom, in 16 steps and $0.8 \%$ global yield.

The same cyclization key step was used for the synthesis of enediol structures. However, the cyclization substrate had to be slightly modified to get the ent-SC- $\Delta^{13}-8$-IsoF and it epimer on the 15 th carbon (Scheme $2 \mathrm{~B}$ ) in 21 steps and in $1.7 \%$ global yield [13].

\subsection{Total synthesis of NeuroF by the group of Zanoni}

The discovery of the NeuroFs in 2008 led by Zanoni group to develop a new strategy for the synthesis of furanoids by making the first total synthesis of one NeuroF, named 7-epi-ST- $\Delta^{8}-10$ neurofuran (Scheme 3) [15].
$\mathrm{HO}$,

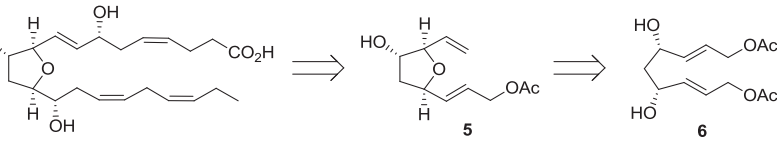

Alkenyl

7-epi-ST- $\Delta^{8}$-10-NeuroF
Scheme 3. Zanoni synthetic strategy.
The key step of the strategy is a diastereo- and enantioselective cyclization using Tsuji-Trost alkylation, starting from diene-diol $\mathbf{6}$, to obtain the furan intermediate $\mathbf{5}$ in good yield (86\%) and good enantiomeric excess (96\%). This intermediate $\mathbf{5}$ allowed the insertion of the lateral chains by Julia-Kocienski coupling and Wittig reaction, to access to the 7 -epi-ST- $\Delta^{8}-10$-neurofuran in 18 steps and $1.6 \%$ global yield.

\subsection{Total syntheses of dihomo-IsoFs, NeuroF and PhytoFs by Galano and Oger}

The recent advances in the field of non-enzymatic lipid metabolites prompted our group to develop synthetic strategies to access all PUFA furan metabolites, even those not yet discovered at that time, such as PhytoFs derived from ALA or dihomo-IsoFs derived from AdA. Thus, two strategies were developed in parallel to access those metabolites. In the first strategy the key step is an intramolecular cyclization of a hydroxyl onto an orthoester (Scheme 4) [9] whereas a Payne rearrangement followed by a basic mediated intramolecular 5-exo-tet cyclization is used in the second one (Scheme 5) [10].

The strategy goes through intermediate $\mathbf{9}$, common to the alkenyl and enediol classes. The regioselective monoprotection of the hydroxyl group in $\alpha$ (compound 10) or $\beta$ (compound $\mathbf{8}$ ) of the ester 9 allows either a 5-exo-tet cyclization (compound 7) or a 5endo-tet cyclization (compound 11). Then, the lateral chains are introduced by Wittig or Horner-Wadsworth-Emmons reactions, 


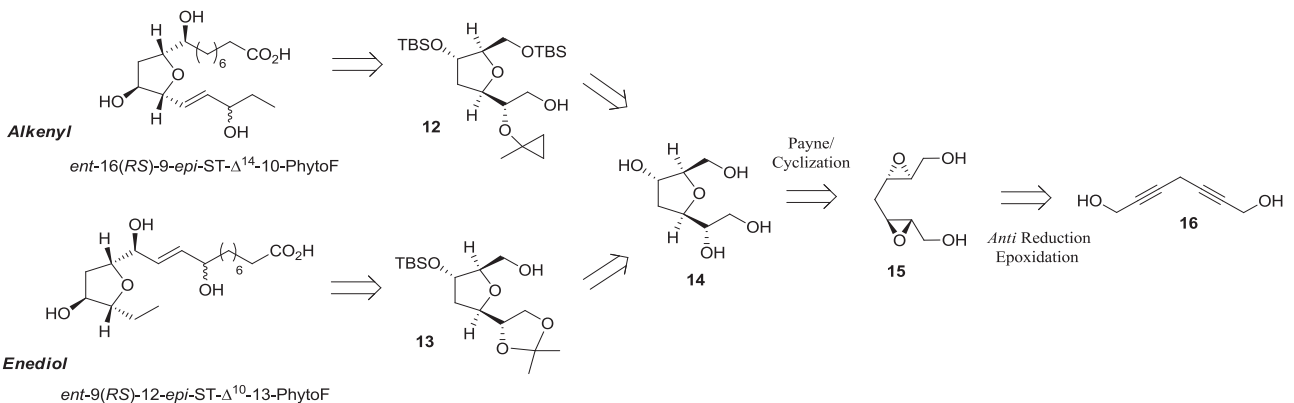

Scheme 4. Galano-Oger first strategy.

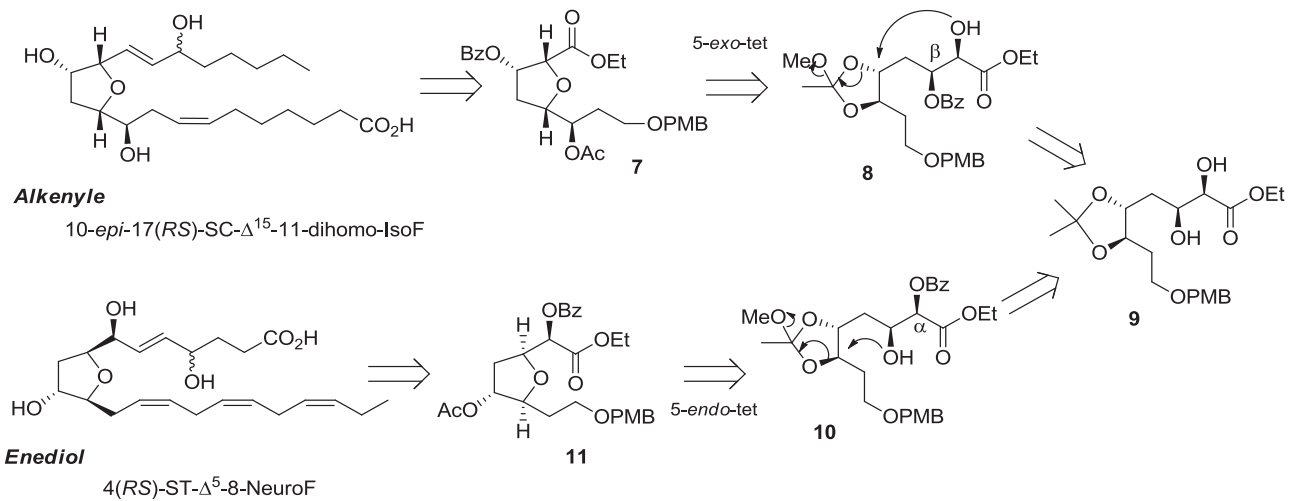

Scheme 5. Galano-Oger second strategy.

leading to the enediol or alkenyl furanoids.

This strategy permitted the first syntheses of dihomo-IsoFs derived from AdA: the 10-epi-17(RS)-SC- $\Delta^{15}$-11-dihomo-IsoF and the $7(R S)-\mathrm{ST}-\Delta^{8}$-11-dihomo-IsoF, as well as the first enediolNeuroF, the $4(R S)-\mathrm{ST}-\Delta^{5}-8-\mathrm{NeuroF}$, in $21-23$ steps and $1.5-2 \%$ global yield $[9,16]$.

The second strategy allows the acquisition of both alkenyl and enediol furanoids through common intermediate 14. The bisepoxide 15 is easily obtained from diyne-diol 16 by a trans-reduction of the diyne followed by a Sharpless bis-epoxidation. Thus, subjected to basic conditions $\left(\mathrm{KOH}, 80^{\circ} \mathrm{C}\right)$, the bis-epoxide leads to a Payne rearrangement followed by an epoxide opening and a 5exo-tet cyclization (compound 14).

The orthogonal protections of the hydroxyl moieties and regioselective deprotection lead to two intermediates (compounds 12 and 13), needed for the lateral chains insertion by Wittig or Horner-Wadsworth-Emmons reactions.

This strategy permitted the first syntheses of PhytoFs derived from ALA: the ent-16(RS)-9-epi-ST- $\Delta^{14}-10$-PhytoF, the ent-16(RS)13-epi-ST- $\Delta^{14}-9$-PhytoF and the ent-9(RS)-12-epi-ST- $\Delta^{10}-13$ PhytoF, in 20 steps and $1 \%$ global yield [10].

\section{Identification and implication of isofuranoids in biological systems}

The synthesis of these novel compounds allows us to expand their measurement in biological samples. To date, the most robust measurement of the isofuranoids is by gas-chromatography-mass spectrometry (GC-MS) or liquid chromatography tandem mass spectrometry (LC-MS/MS). These instruments rely on the mass-tocharge ratio $(\mathrm{m} / \mathrm{z})$ and additional transition ion in the case for LCMS/MS. The disadvantage of GC-MS is the requirement of a derivatizing process and inability to separate isomeric compounds with same molecular weight. Nevertheless, it should be noted the sensitivity of isofuranoids determination also depends on the preparation of the samples. In the literature, not all methods of isofuranoids and other oxidized lipid product measurement are in alignment between researchers; this depend on how lipid portion of the samples are extracted prior to purification by thin layer chromatography (TLC) or solid phase extraction (SPE) for example which are well reported [17-19].

\subsection{Preparation for measurements}

\subsubsection{Mammalian samples}

The detection and quantification of isofuranoids from tissues and/or cells mandatorily require the initial step of sample extraction. To avoid and minimize potential ex vivo generation of lipid metabolites via either enzymatic or non-enzymatic pathways, a small amount of BHT and indomethacin are commonly added into the sample before any homogenization procedures $[18,20]$. Accurate quantities of specimens are often weighed in a highly precise balanced weighing machine, usually based on wet weight. Alternatively, in the case of sampling from cell culture system, the estimated number of cells is determined using various cell counting methods before adding in cell lysis buffer and lipid extracting solvent. It is important to note that having a fully homogenized sample is one of the critical steps in quantifying isofuranoids accurately, as the received shearing force are often closely related to the amount of cellular components being released during the process.

Homogenization of samples is usually performed under physical disruption of tissues with the use of sharp blades or small silica beads and even ultrasound [21]. While these homogenization methods are well recognized, blade homogenizer is widely adopted possibly due to its lower cost and maintenance. The heat generated 
during homogenization is one of the main concerns by general users. Although the rotor-stator homogenizer is efficient in producing high shearing force upon the sample, large amount of heat is also generated from the fast turning rotor and transferred to the homogenizing sample through the attaching blade. Exposing samples to high levels of heat during preparation might contribute to the formation of artefacts, or ex vivo generation of molecules, which ultimately could lead to false positive-negative results. To reduce the amount of heat retained in the sample, one generally uses ice-cold solvents during homogenization as well as cooling the outer surface of the sample tube with ice-cold water or ice itself. In addition, it is encouraged to wash or blend-pass through homogenizing blade with methanol and MilliQ water in between samples, even though they might be from the same treatment group. This additional step prevents cross contamination and maximizes the confidence of gaining highly accurate quantitation in the later stage.

Isofuranoids extraction from different types of tissues using this rotor-stator homogenizer however, is not always reproducible. The extraction of total lipids from tissues is generally based on two established methods, i.e. Folch and Bligh/Dyer. These two methods commonly utilized organic solvents (Folch solution: chloroform:methanol, 2:1; Bligh/Dyer: chloroform:methanol, 1:2) for their lipid extraction [22,23]. Mammalian tissues, e.g. kidney and liver, tend to be hardened when directly exposed to organic solvents, increasing the difficulty in successive homogenization. Other tissue types, like the brain, are comparatively softer even in the presence of organic solvents, but brain homogenates tend to stick to the homogenizing blade, inducing great loss if they were not recovered. Hence, multiple washes of the homogenizing blade with extracting solution are needed and should then be pooled together to maximize the tissue recovery. To overcome the structural changes of tissues in organic solvents, some co-workers [24,25] have successively extracted total lipids by homogenizing the tissues first in PBS, and followed by adding appropriate organic solvents. Alternatively, some other researchers have reported to extract lipids by first grinding freshly harvested tissues into powder form in the presence of liquid nitrogen, and subsequently weigh accurate portion for lipid extraction using organic solvents [26,27]. These two alternative methods provided a detour to total lipid extraction by organic solvents from tissues after they were fully disrupted.

Depending on the target species (e.g. isofuranoids) that are of interest in the study, extracted total lipids from specimens are further processed before quantitative analysis. For example, when determining the levels of isofuranoids, which are mostly esterified as phospholipids, those are usually liberated by adding high molar alkaline in organic solvent, e.g. $1 \mathrm{M} \mathrm{KOH}$ in methanol. These are then purified from polar lipid species via TLC or SPE columns. Finally, the extracts are subjected to qualitative and quantitative analysis commonly via GC-MS or LC-MS/MS. An additional step of derivatization is necessary when using GC-MS [28,29]. Isofuranoids have not been investigated in urine samples, but like for IsoPs they are probably excreted as free forms and conjugated forms (glucoronidates). A validated method for IsoPs was described by Medina et al. [30].

\subsubsection{In plant samples}

Phytofurans (PhytoFs) are newly found oxygenated metabolites produced by non-enzymatic peroxidation of $\alpha$-linolenic acid (ALA) in plants. It was found that PhytoFs are detected in nuts and seeds by LC-MS/MS recently [10]. It is essential for us to extract lipids from the samples properly in order to measure PhytoFs accurately. Three different methods, Soxhlet extraction and solvent extraction have been commonly used by researchers to extract lipids from the nuts and seeds. It is noted that no matter which method is used for lipid extraction, ground dry nuts and seeds samples should be used since ground samples have a higher surface area which gives better yield and also that dry weight is a better reference for comparisons between different samples [31-34].

Soxhlet extraction method extracts the total oil from nuts and seeds with chemical solvent such as petroleum ether [34] or hexane $[33,35]$ in a Soxhlet apparatus for 5-6 h. Afterwards, the solvent is evaporated either under nitrogen gas or in a vacuum evaporator [34,35]. Oil is extracted from the samples through repeating washing with chemical solvent by reflux in Soxhlet apparatus so the solvent can be used repeatedly and the whole extraction process is automatic. Also, depending on the size of the Soxhlet apparatus, the amount of samples used for the extraction can vary from less than $10 \mathrm{~g}$ to $100 \mathrm{~g}$ [34] allowing the extraction of lipids from samples with low lipid content. However, this method takes a long period of time to extract the lipids from the samples and some of the researchers argued that the heating process during reflux in Soxhlet extraction may cause degradation of lipids that are prone to peroxidation such as PUFA, especially DHA [36].

For solvent extraction, the most common method used is Folch extraction method [22]. Briefly, the ground samples are homogenized with Folch solution, followed by agitation using orbital shaker at room temperature. The major advantage of Folch extraction is that less solvent is needed for small amount of samples ( $1 \mathrm{~g}$ in $20 \mathrm{ml}$ of solvent mixture) while for Soxhlet extraction, the amount of solvent used depends on the Soxhlet extractor; the latter requires $100 \mathrm{ml}$ of solvent for $1 \mathrm{~g}$ sample extraction. Folch extraction method also require less preparation time than Soxhlet extraction, in which the whole process only takes approximately 1-2 $\mathrm{h}$ while Soxhlet extraction takes at least $5 \mathrm{~h}$ to complete the extraction. Although the time used in Folch extraction is shorter than Soxhlet extraction, the extract weight is even higher than the one extracted by Soxhlet extraction when same amount of sample were used for the extractions [33]. Furthermore, there are no significant difference between the fatty acids composition of the extract extracted by both methods [33].

It could be surmised that different extraction methods do not affect the lipids composition of the extracts. Extraction method can be chosen based on the nature of your samples. For nuts and seeds having high percentage of lipids, Folch extraction should be used since a small amount of sample $(0.5 \mathrm{~g}-1 \mathrm{~g})$ is sufficient to extract the highest amount of oil extract. For nuts and seeds having low percentage of lipids, Soxhlet extraction should be used in order to handle large amount of samples (>100 g) with less solvent.

\subsection{Mass spectrometry measurement}

In early reports, when IsoFs were first identified [7], GC-MS was the tool of choice by researchers. It requires negative ion chemical ionization and monitors a single ion, 585 in the case of IsoFs and 609 for NeuroFs. However, there is a drawback with the application of GC-MS as it is unable to identify the isomeric forms therefore only the 'total' of the isomers could be determined. Nevertheless, due to the increasing interest in other isofuranoids such as PhytoFs from ALA, dihomo-IsoFs from AdA and NeuroFs from DHA as well as the isomers, the application of LC-MS/MS is currently preferred $[18,19]$. Multiple reaction monitoring (MRM) is highly sensitive and commonly employed in LC-MS/MS. The technical aspects of GC-MS and LC-MS/MS are well described in several reviews [18,19]. LC-MS/ MS approach however, requires the infusion of pure standards to identify the corresponding transition mass ions for the lipid of interest (Table 2). Currently, there are no commercialized standards for isofuranoids ready for researchers, hence the syntheses by organic chemists $[9,10,12-16]$. 
Table 2

Precursor and product ions of isofuranoids determined by gas chromatographymass spectrometry (GC-MS) and liquid chromatography tandem mass spectrometry (LC-MS/MS).

\begin{tabular}{lll}
\hline Analyte & & \\
\hline GC-MS & $\mathrm{m} / \mathrm{z}$ & \\
\hline IsoFs & 585 & \\
NeuroFs & 609 & $\mathrm{Q} 3 \mathrm{~m} / \mathrm{z}$ \\
\hline LC-MS/MS & $Q 1 \mathrm{~m} / \mathrm{z}$ & 193 \\
IsoFs & 369 & 201 \\
7(RS)-ST- $\Delta^{8}-11$-dihomo-IsoF & 397 & 221 \\
10-epi-17(RS)-SC-D ${ }^{15}-11$-dihomo-IsoF & 397 & 201 \\
16(R,S)-13-epi-ST- ${ }^{14}$-9-PhytoF & 343 & 193 \\
NeuroFs (total) & 393 & 123 \\
4(RS)-ST- $\Delta^{5}-8-$ NeuroF & 393 & \\
\hline
\end{tabular}

$m / z$ : mass-ion-ratio; Q1: precursor ion; Q3: transition ion.

\subsubsection{Implications of isofuranoids}

Initially, the measurement of IsoFs and NeuroFs were used to determine the extent of oxidative stress with variable oxygen tension in different models such as fish, rodents, pig, lamb neonates and human (Table 3 ) and thereafter as potential biomarker (Table 4) related to the function of vital organs. As described below, we investigated the types of isofuranoid measurements conducted related to the vital organs and its potential role in the future.

5.2.1.1. Oxygen tension. In vitro peroxidation of AA revealed a plateau from $21 \%$ to $100 \%$ of oxygen tension for the generation of IsoPs, contrary to the constant increase of IsoFs. Concentration of IsoFs was two-fold higher that IsoPs, and the ratio of IsoFs to IsoPs in brain and kidney (two highly oxygenated organs) was the inverse of that of liver, with levels of IsoFs exceeding those of IsoPs by 2.0to 2.3 -fold. These early data suggests that the ratio levels of esterified IsoFs and $\mathrm{F}_{2}$-IsoPs may be able to serve as an index of tissue oxygenation in various organs (Fig. 2).

Complications can arise with more unsaturated precursors like DHA. Indeed, Song et al. showed no difference in NeuroFs concentration at $100 \%$ oxygen tension, probably due to the greater capabilities of the hydroperoxide NeuroF intermediates to generate dioxolane derivatives [37] therefore limiting the total amount of NeuroF.

It is evident that a dynamic augmentation or surgical intubation of oxygen in the biological systems potentially increase the formation of isofuranoids compared to isoprostanoids. Fessel et al. [7] found that IsoFs were predominantly generated above $21 \%$ oxygen tension in bronchoalveolar lavage (BAL) fluid (Table 3). The IsoFs levels were also high in lung tissues of hyperoxic mice but was a transient phenomenon whereas the levels remained high in lung tissues of genetic mice lacking in Cyp1a1gene [38,39]. However, no change in IsoFs was found in lung tissues of lamb exposed to hyperoxia [40]. IsoFs and NeuroFs were elevated in neonates of low gestational age and preterm babies respectively when they were resuscitated at extremely high inspired oxygen level [41,42]. Moreover, in surgical patients requiring tourniquet procedure did not show alteration of IsoFs in the plasma at differential inspired oxygen concentrations [43]. Differential oxygen tension was also found in the brain where certain parts of the brain have higher oxygen tension (white matter) than others (grey matter) $[44,45]$. Noticeably this difference is described in Tables 2 and 3 in which hyperoxic environment elevated IsoFs and NeuroFs in brain tissues of newborn pigs and IsoFs in cognitively unimpaired transgenic mice $[46,47]$. In the marine ecosystem, hypoxia-hyperoxia is a natural event but could be altered in abnormal environment such as climate change or pollution. It was found hyperoxia did not elevate IsoFs and NeuroFs in marine fish muscles despite its high abundance in DHA. Interestingly, hyperoxia acutely augmented dihomo-IsoFs in these fish and was predominant in male gender (Table 3) [48].

5.2.1.2. Brain. As described by Skinner and Feng [44,45], different oxygen tension exists between the white and grey matter where the latter is higher. In relation to this, recently de la Torre et al. observed dihomo-IsoFs, namely 7(RS)-ST- $\Delta^{8}$-11-dihomo-IsoF and 17(RS)-10-epi-SC- $\Delta^{15}$-11-dihomo-IsoF had the most noticeable level in rat and preterm pig brains $[9,16]$. This also corresponded to a previous finding in which adrenic acid was more concentrated in the white matter compared to the grey matter. This finding is important as one needs to be cautious when measuring isofuranoids as it is assumed the brain being rich in DHA, NeuroFs would be the variable metabolite among the isofuranoids determined (Table 4).

Regardless to the oxygen tension, IsoFs and NeuroFs were determined in brain tissues of neurodegenerative diseases as well as neurological related injuries (Table 4). It was shown that IsoFs were higher than the controls in the substantia nigra of Parkinson's disease and dementia but not in multiple system atrophy and Alzheimer's disease (AD) [49]. However, IsoFs and NeuroFs were shown to be higher in the brain cortex of $A D$ transgenic mice compared to the wild-type [8]. Also kainic acid induced epilepsy seizure in adult rats elevated IsoFs levels in the hippocampus and dentate gyrus compared to baseline [50]. IsoFs in the cerebrospinal fluid from traumatic brain injury and subarachnoid hemorrhage patients were also augmented compared to the controls [51] but melatonin supplementation appeared to reduce IsoFs in the cortex tissue of hypoxia-ischemic injury in rat [52]. Viewing these reports, there seem to be a lack of studies in association of diseases and injuries of the brain and the isofuranoid determinations. It would be valuable to determine the different isofuranoids in the brain tissues by differentiating the white and grey matters and specifically frontal, parietal, temporal and occipital cortexes, and cerebellum and brain stem in normal and disease models to see if there is any distinction between them.

5.2.1.3. Heart. The heart pumps oxygenated blood for circulation and this efficacy depends on the rhythm and status of the heart muscle. Measurement of IsoFs related to the heart (Table 4) were mainly focused in plasma and urine of cardiac bypass (CBP) surgery patients [53] in which it was high compared to the controls. Among CBP patients, those with acute kidney injury showed higher IsoFs levels than just CBP patients. However, treatment with acetaminophen to CPB prior to surgery alleviated urinary IsoFs compared to baseline indicating reduction of oxidative stress by acetaminophen [54]. Recently, plasma and urine IsoFs were determined in postoperative atrial fibrillation patients (PoAF) and it was observed that mitochondrial abnormality appeared to favor the generation of IsoF in PoAF condition [55]. Only one study determined IsoFs, NeuroFs and dihomo-IsoFs in heart tissues [16]. It was found among the isofuranoids, dihomo-IsoFs in particular the isomer $7(R S)-\mathrm{ST}-\Delta^{8}-11$ dihomo-IsoF predominated. Interestingly in the same report, NeuroFs namely $4(R S)-S T-\Delta^{5}-8-$ NeuroF was higher in the heart tissue compared to the brain whereas no difference was observed for IsoFs; perhaps this is due to greater dynamics of oxygen tension in the heart compared to the brain, and the higher unsaturation of DHA compared to AA which are more prone to peroxidation. Further, Roy et al. [56] recently observed some anti-arrhythmic event in mice cardiac cells by $4(R S)-\mathrm{ST}-\Delta^{5}-8-\mathrm{NeuroF}$ at high dose, indicating its potential role in the cardiovascular system.

5.2.1.4. Kidney. Reports of IsoFs detection in the renal function 
Table 3

Concentration of isofurans, dihomo-isofurans and neurofurans in different biological samples intentionally induced with hyperoxia.

\begin{tabular}{|c|c|c|}
\hline Study & Sample and concentration & Outcome \\
\hline \multicolumn{3}{|l|}{ Isofurans (IsoFs) } \\
\hline \multicolumn{3}{|l|}{$\overline{\text { Brain }}$} \\
\hline $\begin{array}{r}\text { Cognitively unimpaired Alzheimer's transgenic } \\
\text { (TG) mice exposed to air (A) or hyperoxia (H). }\end{array}$ & $\begin{array}{l}\text { Hippocampus non-TGं: } 8(\mathrm{~A}) \text { and } 10(\mathrm{H}) \mathrm{ng} / \mathrm{g} \\
\text { after } 3 \mathrm{~h} ; 5 \mathrm{ng} / \mathrm{g}(\mathrm{A}) \text { and } 8 \mathrm{ng} / \mathrm{g}(\mathrm{H}) \text { after } 24 \mathrm{~h} \text {. } \\
\text { Hippocampus } T G^{\dagger}: 10(\mathrm{~A}) \text { and } 10 \mathrm{ng} / \mathrm{g}(\mathrm{H}) \text { after } \\
3 \mathrm{~h} ; 8(\mathrm{~A}) \text { and } 28(\mathrm{H}) \mathrm{ng} / \mathrm{g} \text { after } 24 \mathrm{~h} \text {. } \\
\text { Neocortex non- } T G^{\dagger}: 4(\mathrm{~A}) \text { and } 10(\mathrm{H}) \mathrm{ng} / \mathrm{g} \text { after } \\
3 \mathrm{~h} ; 5(\mathrm{~A}) \text { and } 5(\mathrm{H}) \mathrm{ng} / \mathrm{g} \text { after } 24 \mathrm{~h} \text {. } \\
\text { Neocortex } T G^{\dagger}: 7(\mathrm{~A}) \text { and } 6(\mathrm{H}) \mathrm{ng} / \mathrm{g} \text { after } 3 \mathrm{~h} ; 8 \\
\text { (A) and } 27(\mathrm{H}) \mathrm{ng} / \mathrm{g} \text { after } 24 \mathrm{~h} \text {. }\end{array}$ & $\begin{array}{l}\text { IsoFs increased in hippocampus and } \\
\text { neocortex of TG mice at } 24 \mathrm{~h} \text { after a } \\
\text { single hyperoxia exposure. }\end{array}$ \\
\hline $\begin{array}{l}\text { Newborn pigs exposed to } 0,21,40 \text { and } 100 \% \\
\text { oxygen. }\end{array}$ & $\begin{array}{l}\text { Prefrontal cortex tissue: } 14.69 \pm 3.0(0 \%) \\
36.70 \pm 10.5(21 \%), 48.99 \pm 21.1(40 \%) \text { and } \\
55.99 \pm 22.6(100 \%) n g / g\end{array}$ & $\begin{array}{l}\text { Dose-dependent increase of IsoFs in } \\
\text { brain. }\end{array}$ \\
\hline \multicolumn{3}{|c|}{ 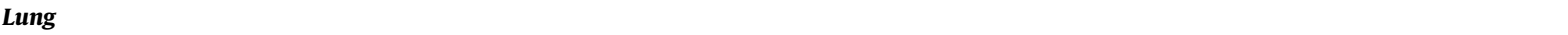 } \\
\hline Mice & $\begin{array}{l}\text { Mouse: } 210 \pm 30 \mathrm{pg} / \mathrm{mL} \text { bronchoalveolar lavage } \\
\text { fluid; } 24 \text { (air) vs } 90\left(>98 \% \mathrm{O}_{2}\right) \text { pg mg protein } \\
\text { lung tissue. }\end{array}$ & $\begin{array}{l}\text { The formation of IsoFs becomes } \\
\text { increasingly favored as oxygen tension } \\
\text { increasedabove } 21 \% \text {. }\end{array}$ \\
\hline $\begin{array}{l}\text { Lamb exposed to room air or } 95 \% \mathrm{O}_{2} \text { or } 95 \% \\
\mathrm{O}_{2} \text { plus nitric oxide }(5-10 \mathrm{ppm}) \text {. }\end{array}$ & Lung tissue: no data shown. & $\begin{array}{l}\text { There was no difference in lung tissue } \\
\text { IsoFs between treatments. }\end{array}$ \\
\hline $\begin{array}{l}\text { Extremely low gestational age neonate (ELGAN) } \\
\text { resuscitated with a lower (30\%) or higher } \\
\left.\text { (90\%) fraction of inspired oxygen ( } \mathrm{F}_{\mathrm{IO} 2}\right) \text { with }\end{array}$ & $\begin{array}{l}\text { 30\% resuscitation: no data provided. } \\
90 \% \text { resuscitation: } 8 \mathrm{ng} / \mathrm{mg} \mathrm{Cr}(\mathrm{BPD}) \text { and } 4 \mathrm{ng} / \mathrm{mg} \\
\mathrm{Cr} \text { (no } \mathrm{BPD} \text { ) in urine day } 7 \text { after birth. }\end{array}$ & $\begin{array}{l}\text { Oxidative stress increased significantly } \\
\text { in the } 90 \% \text { oxygen group compared to } \\
30 \% \text { oxygen group first week after birth }\end{array}$ \\
\hline
\end{tabular}

Isofurans (IsoFs)

gnitively unimpaired Alzheimer's transgenic

$3 \mathrm{~h} ; 8(\mathrm{~A})$ and $28(\mathrm{H}) \mathrm{ng} / \mathrm{g}$ after $24 \mathrm{~h}$.

ng/g after

(A) and $27(\mathrm{H}) \mathrm{ng} / \mathrm{g}$ after $24 \mathrm{~h}$.

Prefrontal cortex tissue: $14.69 \pm 3.0(0 \%)$

$36.70 \pm 10.5(21 \%), 48.99+21.1(40 \%)$ and

Mouse: $210 \pm 30 \mathrm{pg} / \mathrm{mL}$ bronchoalveolar lavage fluid; 24 (air) vs 90 (>98\% $\left.\mathrm{O}_{2}\right)$ pg mg protein lung tissue.

$30 \%$ resuscitation: no data provided.

$\mathrm{Cr}$ (no BPD) in urine day 7 after birth.

and without bronchopulmonary dysplasia (BPD).

Mice lacking Cyp1a1 gene (more susceptible to hyperoxic lung injury) and C57BL/6J wildtype (WT) mice under hyperoxia environment for $24-72 \mathrm{~h}$.

Mice lacking Cyp1a1 gene (more susceptible to hyperoxic lung injury) and C57BL/6J wildtype (WT) mice in room air (A) or exposed to $>95 \%$ oxygen for 24,48 , or $72 \mathrm{~h}$

\section{Others}

Planned surgical patients with isolated upperlimb trauma requiring the pneumatic arterial tourniquet procedure and inspired with 30 , 50 , or $80 \%$ oxygen concentrations.

Marine fish muscles

Preterm babies resuscitated with inspired oxygen $\left(\mathrm{F}_{\mathrm{IO} 2}\right)$.

\section{Dihomo-isofurans (Dihomo-IsoFs)}

\section{Others}

Marine fish

\section{Neurofurans (NeuroFs) \\ Brain \\ Newborn pigs exposed to 0, 21, 40 and 100\% oxygen.}

\section{others}

Preterm babies resuscitated with inspired oxygen $\left(\mathrm{F}_{\mathrm{IO} 2}\right)$.

Marine fish
Lung tissue $W T^{\dagger}: 0.85$ (air) and 1.8 (24 h) ng/mg protein.

Lung tissueCyp $1 a 1^{-/-\dagger}: 0.75$ (air), $1.1(24 \mathrm{~h}$ ) and $0.95(48 \mathrm{~h}) \mathrm{ng} / \mathrm{mg}$ protein.

Lung tissue $W T^{\dagger}: 0.9(\mathrm{~A}), 1.4(24 \mathrm{~h}), 0.5(48 \mathrm{~h})$ and $0.7(72 \mathrm{~h}) \mathrm{ng} / \mathrm{mg}$ protein.

Lung tissueCyp1a1 ${ }^{-/-\dagger}$ : 0.8 (A), 0.7 (24 h), 1.2

$(48 \mathrm{~h})$ and $1.0(72 \mathrm{~h}) \mathrm{ng} / \mathrm{mg}$ protein.

Liver tissue $W T^{\dagger}: 0.5(\mathrm{~A}), 0.6(24 \mathrm{~h}), 0.5(48 \mathrm{~h})$ and

$0.75(72 \mathrm{~h}) \mathrm{ng} / \mathrm{mg}$ protein.

Liver tissue $W T^{\dagger}$ : 0.5 (A), $0.6(24 \mathrm{~h}), 0.5$ (48 h) and

$0.7(72 \mathrm{~h}) \mathrm{ng} / \mathrm{mg}$ protein.

Liver tissueCyp1a1 ${ }^{-{ }^{-\dagger}}$ : 0.7 (A), 0.4 (24 h), 0.8

$(48 \mathrm{~h})$ and $0.82(72 \mathrm{~h}) \mathrm{ng} / \mathrm{mg}$ protein.

Plasma: 6.11 (30\%), 6.65 (50\%) and 5.94 (80\%) $\mathrm{nmol} / \mathrm{L}$ prior oxygen inspiration i.e. baseline; 6.02 (30\%), 5.70 (50\%) and $4.62(80 \%) \mathrm{nmol} / \mathrm{L}$

$15 \mathrm{~min}$ after inspired oxygen.

Male $^{\dagger}: 0.75$ (baseline) vs 1.8 (hyperoxia) ng/g muscle

Female $^{\dagger}$ : 3.0 (baseline) vs 1.8 (hyperoxia) ng/g muscle

Control urine: $211 \pm 239$ (PD 1), $547 \pm 651$ (PD7) and $167 \pm 188$ (PD 28) signal units of UPLC-MS/ MS per $\mathrm{mL}$

BPD urine: $455 \pm 188$ (PD 1), $612 \pm 548$ (PD7)

and $198 \pm 219$ (PD 28) signal units of UPLC-MS/

MS per $\mathrm{mL}$

Male $^{\dagger}$ : 0.80 (baseline) vs 3.1 (hyperoxia) ng/g muscle.

Female $^{\dagger}$ : 0.5 (baseline) vs 0.8 (hyperoxia) ng/g muscle.

Prefrontal cortex tissue: $6.07 \pm 2.0$ (control),

$6.84 \pm 2.7$ (21\%), $13.98 \pm 7.8(40 \%)$ and

$15.81 \pm 10.1(100 \%) \mathrm{ng} / \mathrm{g}$.

Control urine: $16 \pm 26$ (PD 1), $44 \pm 38$ (PD7) and $23 \pm 28$ (PD 28) signal units of UPLC-MS/MS per $\mathrm{mL}$

BPD urine: $20 \pm 18$ (PD 1), $54 \pm 44$ (PD7) $34 \pm 19$ (PD 28) signal units of UPLC-MS/MS per mL Male $^{\dagger}$ : 5.0 (baseline) vs 10.0 (hyperoxia) ng/g muscle

Female $^{\dagger}: 10.0$ (baseline) vs 4.0 (hyperoxia) ng/g muscle

WT lung had increased IsoFs after $24 \mathrm{~h}$ hyperoxia exposure and Cyp1a1( $\left(^{-/}\right)$ mice lung had increased IsoFs after 48 -72 h.Thereafter, the concentrations returned to 'air' level.

Hyperoxia leads to lung injury but it is transient in WT but not in Cyp1a1-/mice.

Different concentration of inspired oxygen did not alter IsoFs.

Hyperoxia did not alter IsoFs concentration in fish muscles.

Increased IsoFs during the first week after birth.

Hyperoxia significantly elevated dihomo-IsoFs, namely 10-epi-17(RS)SC- $\Delta^{15}-11$-dihomo-isofuran in male fish muscle.

Dose-dependent increase of NeuroFs in brain.

Augmented NeuroFs by hyperoxia was reduced after one-week $\mathrm{PD}$. 
Table 4

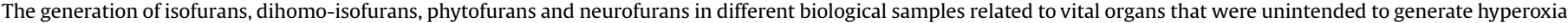
condition in the study.

\begin{tabular}{l} 
Study \\
\hline$\frac{\text { Brain }}{\text { IsoFs }}$ \\
Parkinson's disease (PD), multiple system \\
atrophy (MSA), dementia with Lewy body \\
(DLB) disease and Alzheimer's disease (AD) \\
patients.
\end{tabular}

Alzheimer disease $\operatorname{Tg} 2576$ transgenic mice

Kainic acid-induced with seizure (status epilepticus) in adult rats.

Comatose severe aneurysmal subarachnoid hemorrhage (aSAH) and traumatic brain injury (TBI) patients.

Rat with cerebral hypoxia-ischemia (HI) injury and melatonin (Met) treatment.

Preterm pig brain cortex

Rat brain

Dihomo-IsoFs

Preterm pig brain cortex

Rat brain

NeuroFs

Alzheimer disease $\operatorname{Tg} 2576$ transgenic mice.

Preterm pig brain cortex

Rat brain

Heart

Cardiac surgery patients with developed acute kidney injury (AKI)

Elective cardiac bypass (CPB) surgery children patients treated with acetaminophen or placebo prior to surgery.

Rat heart

Cardiac bypass (CPB) surgery patients treated with acetaminophen or placebo prior to surgery.

Postoperative atrial fibrillation (PoAF) patients.
Sample and concentration

Reference

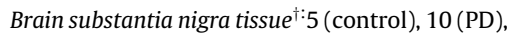
10 (DLB), 4 (MSA) and 3 (AD) ng/g.

Cortex tissues: 10.5 (control) vs 14.3 ( $\operatorname{Tg} 2576$ ) $\mathrm{ng} / \mathrm{g}$.

Cerebellum ${ }^{\dagger}: 80$ (control) vs $100(\operatorname{Tg} 2576) \mathrm{ng} / \mathrm{g}$. Hippocampus $^{\dagger}: 1.25 \mathrm{ng} / \mathrm{g}$ tissue before seizure, and $4.5 \mathrm{ng} / \mathrm{g}$ tissue $(16 \mathrm{~h})$ and $3.25(48 \mathrm{~h}) \mathrm{ng} / \mathrm{g}$ tissue after seizure.

Dentate gyrus ${ }^{\dagger}: 1.0 \mathrm{ng} / \mathrm{g}$ tissue before seizure, and $6.75 \mathrm{ng} / \mathrm{g}$ tissue (16 h) and 3.25 (48 h) ng/g tissue after seizure.

Cerebellum $^{\dagger}: 0.75 \mathrm{ng} / \mathrm{g}$ tissue before seizure, and $1.0 \mathrm{ng} / \mathrm{g}$ tissue $(16 \mathrm{~h})$ and $1.25(48 \mathrm{~h}) \mathrm{ng} / \mathrm{g}$ tissue after seizure.

$C S F^{\dagger}$ : 0.50 (control) and $2.10 \mathrm{nmol} / \mathrm{L}(\mathrm{aSAH})$

patients; 0.50 (control) and $1.80 \mathrm{nmol} / \mathrm{L}$ (TBI patients.

Cerebral right cortex tissue: 0.11 (control), 1.56

(HI) and $0.84 \mathrm{HI}-\mathrm{Met} \mathrm{ng} / \mathrm{mg}$.

Cortex tissue ${ }^{\dagger}: 2 \mathrm{ng} / \mathrm{g}$ (prefrontal) and $6 \mathrm{ng} / \mathrm{g}$

(medial prefrontal cortex)

Brain tissue $e^{\dagger}: 3.5 \mathrm{ng} / \mathrm{g}$

Cortex tissue $^{\dagger}: 11$ (prefrontal) and 16 (medial prefrontal cortex) ng/g of $17(R S)-10$-epi-SC $\Delta^{15}$ 11-dihomo-Isofuran.

Brain tissue $^{\dagger}: 280 \mathrm{ng} / \mathrm{g}$ of 7(RS)-ST- $\Delta^{8}-11$ dihomo-Isofuran and $3 \mathrm{ng} / \mathrm{g}$ of 17(RS)-10-epiSC $\Delta^{15}$-11-dihomo-Isofuran.

Cortex tissues: 156.2 (wild-type) vs 99.3 $\left(p 47^{\text {phox }}\right) \mathrm{ng} / \mathrm{g} ; 109.1$ (wild-type) vs $173.2(\mathrm{Tg}$ 2576) ng/g.

Cortex tissue $^{\dagger}: 3 \mathrm{ng} / \mathrm{g}$ (prefrontal) and $5 \mathrm{ng} / \mathrm{g}$ (medial prefrontal cortex).

Brain tissue $e^{\dagger}: 0.2 \mathrm{ng} / \mathrm{g}$ (total neurofuran) and $0.02 \mathrm{ng} / \mathrm{g}\left(4(R S)-\mathrm{ST}-\Delta^{5}-8\right.$-Neurofuran).

Plasma: 32 (baseline), 58 (post cardiac bypass), 57 (ICU) and 30 (day 3 post-operation) $\mathrm{pg} / \mathrm{mL}^{\dagger}$; $37.7 \pm 5.7$ (control) vs $27.4 \pm 5.4(\mathrm{AKI}) \mathrm{pg} / \mathrm{mL}$. Urine: 2.7 (baseline), 5.5 (post cardiac bypass) 8.5 (ICU) and 4 (day 3 post-operation) $\mathrm{ng} / \mathrm{mL}$ $\mathrm{Cr}^{\dagger} ; 4.2 \pm 0.5$ (smokers) vs $2.5 \pm 0.3$ (nonsmokers) $\mathrm{ng} / \mathrm{mL} \mathrm{Cr}$ among the patients; $3.3 \pm 0.5 \mathrm{ng} / \mathrm{mL} \mathrm{Cr}$ (control) vs $2.2 \pm 0.3$ (AKI) $\mathrm{ng} / \mathrm{mL} \mathrm{Cr}$.

Acetaminophen plasma ${ }^{\dagger}: 85$ (baseline) and 120 (post $\mathrm{CPB}$ ) $\mathrm{pg} / \mathrm{mL}$.

Acetaminophen urine ${ }^{\dagger}: 15 \mathrm{pg} / \mathrm{mg} \mathrm{Cr}$ (baseline) and 30 (post $\mathrm{CPB}$ ) ng/mg Cr.

Heart tissue ${ }^{\dagger}: 3.0 \mathrm{ng} / \mathrm{g}$

Placebo plasma ${ }^{\dagger}$ : 68.7 (baseline) and 109.5 (60 min CPB) pg/mL.

Acetaminophen plasma ${ }^{\dagger}: 61.7 \mathrm{pg} / \mathrm{mL}$ (baseline) and 80 (60 $\mathrm{min}$ CPB) $\mathrm{pg} / \mathrm{mL}$

Placebo urine ${ }^{\dagger}: 2.78 \mathrm{ng} / \mathrm{mg} \mathrm{Cr}$ (baseline) and

8.33 (post-CPB) ng/mg Cr.

Acetaminophen urine ${ }^{\dagger}: 3.11 \mathrm{ng} / \mathrm{mg} \mathrm{Cr}$ (baseline) and 9.22 (post-CPB) ng/mg Cr.

No PoAF plasma ${ }^{\dagger}$ : 60 (baseline), (end of surgery) and 55 (day 2 post operation) pg/mL.

PoAF plasma ${ }^{\dagger}$ : 68 (baseline), 68 (end of surgery) and 60 (day 2 post operation) $\mathrm{pg} / \mathrm{mL}$.

No PoAF urine ${ }^{\dagger}$ : 2 (baseline), 6 (end of surgery)
IsoFs increased preferentially in PD and DLB patients and may be related to the relative intracellular hyperoxia due to mitochondrial dysfunction.

IsoFs are elevated in $\mathrm{Tg} 2576$ brain.

Increased IsoFs after seizure induction in hippocampus and dentate gyrus. No change in cerebellum. The hippocampal IsoFs correlated with mitochondrial oxidative stress and reoxgyenation after a transient hypoxia.

IsoFs measurement could assist in management of comatose-neurological care patients.

Melatonin protected brain injury.

Higher IsoFs concentration in medial prefrontal cortex tissues.

No difference in the level of IsoFs between brain and heart.

17(RS)-10-epi-SC $\Delta^{15}$-11-dihomo-IsoF was identified in brain tissue.

Among the isofuranoids, 7(RS)-ST- $\Delta^{8}-11-$ dhihomo-IsoF predominated in the brain tissue.

Elevated levels of NeuroFs are found in $\operatorname{Tg} 2576$ brain cortex.

No difference between brain tissue types.

Neurofuran was synthesized and identified in heart and brain tissues.

Hemoprotein induced in AKI increased lipid peroxidation.

Compared to placebo (data not provided), acetaminophen attenuated the IsoFs increase in plasma during $\mathrm{CPB}$.

No difference in the level of IsoFs between brain and heart.

Plasma IsoFs peaked 60 min during CPB and returned to baseline level at postoperative day 1. Urine IsoFs increased with time and returned to baseline at postoperative day 1 .

Mitochondrial dysfunction and elevated oxygen concentration favored the development of IsoFs in PoAF. 


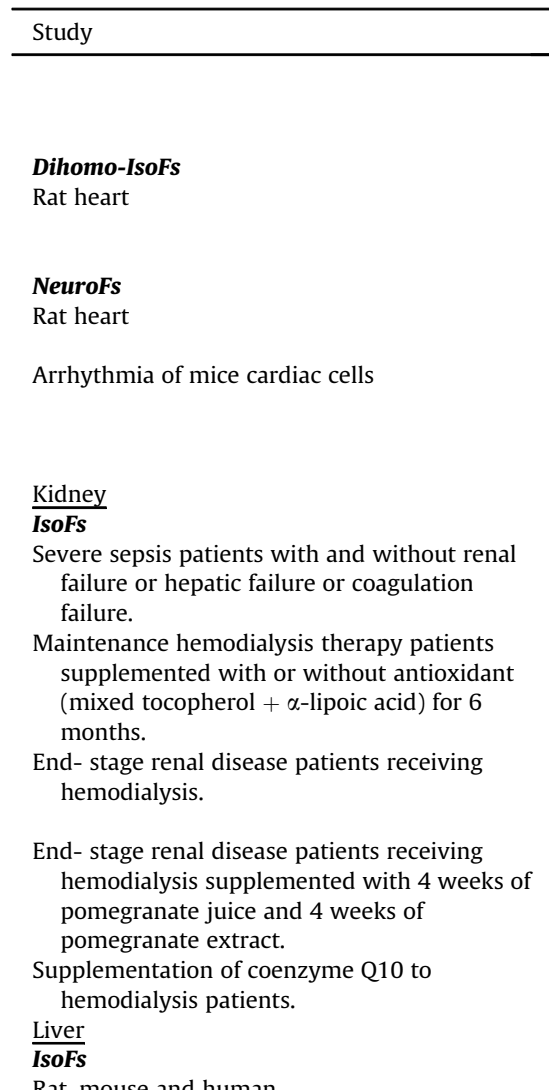

Rat, mouse and human.

Severe sepsis patients with and withouthepatic failure.

\section{NeuroFs}

Mice with or without $\mathrm{CCl}_{4}$ treatment, $p 47^{\text {phox }}$ knock-out mice

\section{Lung}

Mice with cytoplasmic domain mutation (BMPR2 $^{\text {R899X). }}$.

Transgenic mice with low levels of tissue factor (LTF) and wild type (WT) exposed to lipopolysaccharide (LPS), and patients alveolar hemorrhage

Lung transplant recipients with primary graft dysfunction (PGD) and controls (non-PGD).

\section{Others}

IsoFs

Rat and human.

Mice low-high iron proximal colon after azoxymethane (AOM) or saline (control) treatment.

Severe sepsis patients with and coagulation failure.

Spinal (SA) or general (GA) anesthesia in ischemia/reperfusion of the leg surgery

Normal pregnancy versus pre-eclampsia.
Sample and concentration

Outcome

Reference

and 2.5 (day 2 post operation) ng/mg Cr.

PoAF urine ${ }^{\dagger}: 2$ (baseline), 9 (end of surgery) and 2.8 (day 2 post operation) $\mathrm{ng} / \mathrm{mg} \mathrm{Cr}$.

Heart tissue $^{\dagger}: 140 \mathrm{ng} / \mathrm{g}$ of $7(R S)-\mathrm{ST}-\Delta^{8}-11$ dihomo-Isofuran and $3 \mathrm{ng} / \mathrm{g}$ of 17(RS)-10-epi$\mathrm{SC} \Delta^{15}$-11-dihomo-Isofuran).

Heart tissue ${ }^{\dagger}: 0.2 \mathrm{ng} / \mathrm{g}$ (total neurofuran) and $0.11 \mathrm{ng} / \mathrm{g}\left(4(R S)-\mathrm{ST}-\Delta^{5}-8-\right.$ Neurofuran). $4(R S)-S T-\Delta^{5}-8$-Neurofuran reduced arrhythmia.

Plasma without renal failure $e^{\dagger}: 250 \mathrm{pg} / \mathrm{mL}$. Plasma with renal failure ${ }^{\dagger}: 1250 \mathrm{pg} / \mathrm{mL}$. Plasma with coagulation failure ${ }^{\dagger}: 1500 \mathrm{pg} / \mathrm{mL}$ Placebo plasma: $0.89 \pm 1.9$ (baseline) and $0.79 \pm 1.36$ ( 6 months $) \mathrm{ng} / \mathrm{mL}$. Antioxidant plasma: $0.69 \pm 1.31 \mathrm{ng} / \mathrm{mL}$ (baseline) and $0.65 \pm 0.90$ ( 6 months) $\mathrm{ng} / \mathrm{mL}$. Baseline: $<0.25-\geq 0.73 \mathrm{ng} / \mathrm{mL}$ plasma. 6-month after hemodialysis: $<0.26-\geq 0.73 \mathrm{ng} /$ mL plasma.

Plasma: Not reported.

Plasma: $141 \pm 67.5$ (before) and $72.2 \pm 37.5$ (after) $\mathrm{pg} / \mathrm{mL}$ supplementation.

$2\left(-\mathrm{CCl}_{4}\right)$ vs $30 \mathrm{ng} / \mathrm{g}\left(+\mathrm{CCl}_{4}\right)$ liver tissue. Plasma without hepatic failure ${ }^{\dagger}: 500 \mathrm{pg} / \mathrm{mL}$. Plasma with hepatic failure ${ }^{\dagger}: 1300 \mathrm{pg} / \mathrm{mL}$.

Liver tissues: 141.3 (control), and 412.2 (1 h) and $1330.6(2.5 \mathrm{~h}) \mathrm{ng} / \mathrm{g}$ post $\mathrm{CCl}_{4}$ injection.

Lung tissue ${ }^{\dagger}: 11 \mathrm{ng} / \mathrm{g}$ (control) and $21 \mathrm{ng} / \mathrm{g}$ (BMPR2 ${ }^{\text {R899X) }}$.

WT lung tissue ${ }^{\dagger}:$ 1.0-1.5 (-LPS) and 1.5-2.1 (+LPS) ng/g.

LTF lung tissue $e^{\dagger}$ 1.0-2.8 (-LPS) and 3.0-5.0 (+LPS) $\mathrm{ng} / \mathrm{g}$.

Human bronchoalvelar lavage $e^{\dagger}$ : increment with sampling aliquot, 50, 60, 150, $150 \mathrm{pg} / \mathrm{mL}$. Non-PGD plasma: $31.9 \mathrm{pg} / \mathrm{mL}$.

PGD plasma: $39.7 \mathrm{pg} / \mathrm{mL}$.

PDG with non-smoker lung plasma: $34.6 \mathrm{pg} / \mathrm{mL}$.

PDG with smoker's lung plasma: $66.9 \mathrm{pg} / \mathrm{mL}$.

Rat: $3.3 \pm 0.3 \mathrm{ng} / \mathrm{mL}$ urine; $334 \pm 80 \mathrm{pg} / \mathrm{mL}$ plasma; 0.32 (control) vs 0.05 (n-

acetylcysteine) vs 0.12 ( $\alpha$-lipoic acid) $\mathrm{ng} / \mathrm{mL}$ plasma ${ }^{\dagger}$;

Human: $5.8 \pm 1.0 \mathrm{ng} / \mathrm{mL}$ urine; $71 \pm 10 \mathrm{pg} / \mathrm{mL}$ plasma.

Control ${ }^{\dagger}$ : 5.5 (low iron) and 2.5 (high iron) ng/g $A O M^{\dagger}: 2.8$ (low iron) and 3.0 (high iron) ng/g

Plasma without coagulation failure ${ }^{\dagger}: 300 \mathrm{pg} / \mathrm{mL}$. Plasma with coagulation failure ${ }^{\dagger}: 1500 \mathrm{pg} / \mathrm{mL}$. Plasma GA: 8.80 (baseline), 8.70 (2 h), 8.80 $(3.5 \mathrm{~h})$ and $5.80(24 \mathrm{~h}) \mathrm{nmol} / \mathrm{L}$ Plasma SA: 8.80 (baseline), 8.30 (2 h), 5.50 $(3.5 \mathrm{~h})$ and $5.40(24 \mathrm{~h}) \mathrm{pmol} / \mathrm{L}$. Plasma from maternal blood ${ }^{\dagger}: 2.00$ (normal) and 2.50 (pre-eclampsia) nmol/L. Plasma from cord blood ${ }^{\dagger}: 12.00$ (normal) and 14.00 (pre-eclampsia) nmol/L.
Among the isofuranoids, $7(R S)-\mathrm{ST}-\Delta^{8}-11-$ dhihomo-IsoF predominated in the heart tissue.

Higher 4(RS)-ST- $\Delta^{5}-8$ - neurofurans level in heart tissue than the brain was found. Higher concentration $(1 \mu \mathrm{M})$ of $4(R S)-S T-\Delta^{5}-8$ Neurofuran compared to lower concentration $(0.1 \mu \mathrm{M})$ showed anti-arrhythmic effect in cardiac cells.

IsoFs are highly associated with renal in critically ill patients with severe sepsis.

No improvement of oxidative stress by antioxidant supplementation to hemodialysis patients.

Higher level of IsoFswas associated with increased resistance to erythropoiesis stimulating agents.

Supplementation had no effect on the level of IsoFs.

Plasma IsoFs concentrations decreased after coenzyme Q10 supplementation.

The formation of IsoFs by $\mathrm{CCl}_{4}$ in liver. IsoFs are highly associated with hepatic failure in critically ill patients with severe sepsis.

Acute increase of NeuroFs after $\mathrm{CCl}_{4}$ treatment in liver.

Mice with cytoplasmic domain mutation show increased IsoFs levels.

Tissue factor deficiency potentially increased intraalveolarhaemorrhage and LPS leading to enhanced IsoFs levels.

IsoFswas higher in patients with PGD after smoker lung transplantation compared with patients without PGD development.

IsoFs detectable in different samples.

Iron overload did not affect colon tissue levels of IsoFs.

IsoFs are highly coagulation failure in critically ill patients with severe sepsis. IsoFs were lower in patients undergoing SA compared with patients undergoing GA.

Significant elevation of IsoF in maternal plasma but not cord blood.
[65] 
Table 4 (continued)

\begin{tabular}{|c|c|c|c|}
\hline Study & Sample and concentration & Outcome & Reference \\
\hline Age macular degeneration (AMD) patients. & $\begin{array}{l}\text { Non-AMD plasma: } 0.15 \pm 0.18 \mathrm{ng} / \mathrm{mL} \text {. } \\
\text { AMD plasma: } 0.22 \pm 0.38 \mathrm{ng} / \mathrm{mL} \text {. }\end{array}$ & Potential role of IsoFs in AMD pathogenesis. & {$[68,69]$} \\
\hline $\begin{array}{l}\text { Age macular degeneration (AMD) patients } \\
\text { before and after antioxidant } \\
\text { supplementation. }\end{array}$ & $\begin{array}{l}\text { Non-AMD plasma: } 0.20 \pm 0.072 \text { (before) and } \\
0.17 \pm 0.048 \text { (after) } \mathrm{ng} / \mathrm{mL} \text {. } \\
\text { AMD plasma: } 0.24 \pm 0.20 \text { (before) and } \\
0.25 \pm 0.29 \text { (after) } \mathrm{ng} / \mathrm{mL} \text {. }\end{array}$ & Antioxidant failed to reduce IsoFs in AMD. & {$[68,69]$} \\
\hline Canadian Inuits & Plasma:20.86 (18.90-23.02 range) pg/mL & $\begin{array}{l}\text { IsoFs correlated with visceral adiposity and } \\
\text { smoking was related to lower plasma levels of } \\
\text { IsoFs due to lower ambient levels of tissue } \\
\text { oxygen among smokers. }\end{array}$ & [70] \\
\hline Canadian Inuits & $\begin{array}{l}\text { Plasma from blood with: }<200 \text { Se } \mu \mathrm{g} / \mathrm{L}, 29.98 \mathrm{pg} / \\
\mathrm{mL} \text { IsoFs; } \geq 200 \text { and }<340 \text { Se } \mu \mathrm{g} / \mathrm{L}, 17.53 \mathrm{pg} / \mathrm{mL} \\
\text { IsoFs; } \geq 340 \text { Se } \mu \mathrm{g} / \mathrm{L}, 18.14 \mathrm{pg} / \mathrm{mL} \text { IsoFs. }\end{array}$ & $\begin{array}{l}\text { Plasma IsoFs decreased with increasing tertiles } \\
\text { of blood Se. }\end{array}$ & [71] \\
\hline $\begin{array}{l}\text { Storage of leukoreduced human red blood cells } \\
\text { (RBC). }\end{array}$ & $\begin{array}{l}\text { Supernatant of stored RBCं: } 5 \text { days: } 75 \mathrm{pg} / \mathrm{mL} ; 12 \\
\text { days: } 90 \mathrm{pg} / \mathrm{mL} ; 40 \text { days: } 170 \mathrm{pg} / \mathrm{mL} ; 47 \text { days: } \\
190 \mathrm{pg} / \mathrm{mL} \text {. } \\
\text { Supernatant washing of } R B C^{\dagger}: 55 \mathrm{pg} / \mathrm{mL} \text { (pre- } \\
\text { wash) vs } 17 \mathrm{pg} / \mathrm{mL} \text { (post-wash). }\end{array}$ & $\begin{array}{l}\text { Linear increase in IsoFs in RBC supernatant with } \\
\text { storage time but decreased if washed. }\end{array}$ & [72] \\
\hline $\begin{array}{l}\text { Infants with normal gestational period } \\
\text { Dihomo-IsoFs }\end{array}$ & Serum: $0.015-147 \mathrm{nmol} / \mathrm{L}$ range. & No outcome. & [73] \\
\hline Pine nut, walnut, chia seed and flax seed & $\begin{array}{l}\text { Nuts and seeds }{ }^{\dagger}: 0.3 \text { (pine), } 9 \text { (walnut), } 6 \text { (chia) } \\
\text { and } 0.7 \text { (flax) ng/g of ent-16-(RS)-13-epi-ST- } \\
\Delta^{14}-9 \text {-Phytofuran. }\end{array}$ & $\begin{array}{l}\text { ent-16-(RS)-13-epi-ST- } \Delta^{14}-9-\mathrm{PhytoF} \\
\text { predominated in walnut and chia seeds. }\end{array}$ & {$[10]$} \\
\hline \multicolumn{4}{|l|}{ NeuroFs } \\
\hline Infants with normal gestational period & Serum: $0.013-14.5 \mathrm{nmol} / \mathrm{L}$ range. & No outcome. & {$[73]$} \\
\hline
\end{tabular}

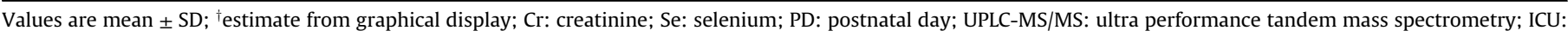
intensive care unit.

mainly focused on hemodialysis patients (Table 4) in particular to reduce oxidative stress. It was shown antioxidant supplementation of mixed tocopherols with $\alpha$-lipoic acid or pomegranate juice had no effect on the IsoFs level in plasma but supplementation of coenzyme Q10 decreased plasma IsoFs concentration in hemodialysis patients [57-60]. However, in critically ill patients with sepsis and renal failure showed multiple increase in IsoFs concentration in plasma compared to severe sepsis patients [61]. To date, no reports on dihomo-IsoFs and NeuroFs levels in relation to kidney disorders were found.
5.2.1.5. Liver. Liver is the main organ for the synthesis, metabolism and storage of PUFA. Despite this, only a handful of studies on isofuranoids and liver function were found in the literature (Table 4), probably because the liver oxygen tension is the lowest of all organs, therefore the isoprostanoids should predominate (ref Fessel 2002). It was shown severe sepsis patients with hepatic failure had higher levels of plasma IsoFs compared to severe sepsis patients [61]. Moreover, an acute increase of NeuroFs was identified in mice liver when treated with carbon tetrachloride [8].

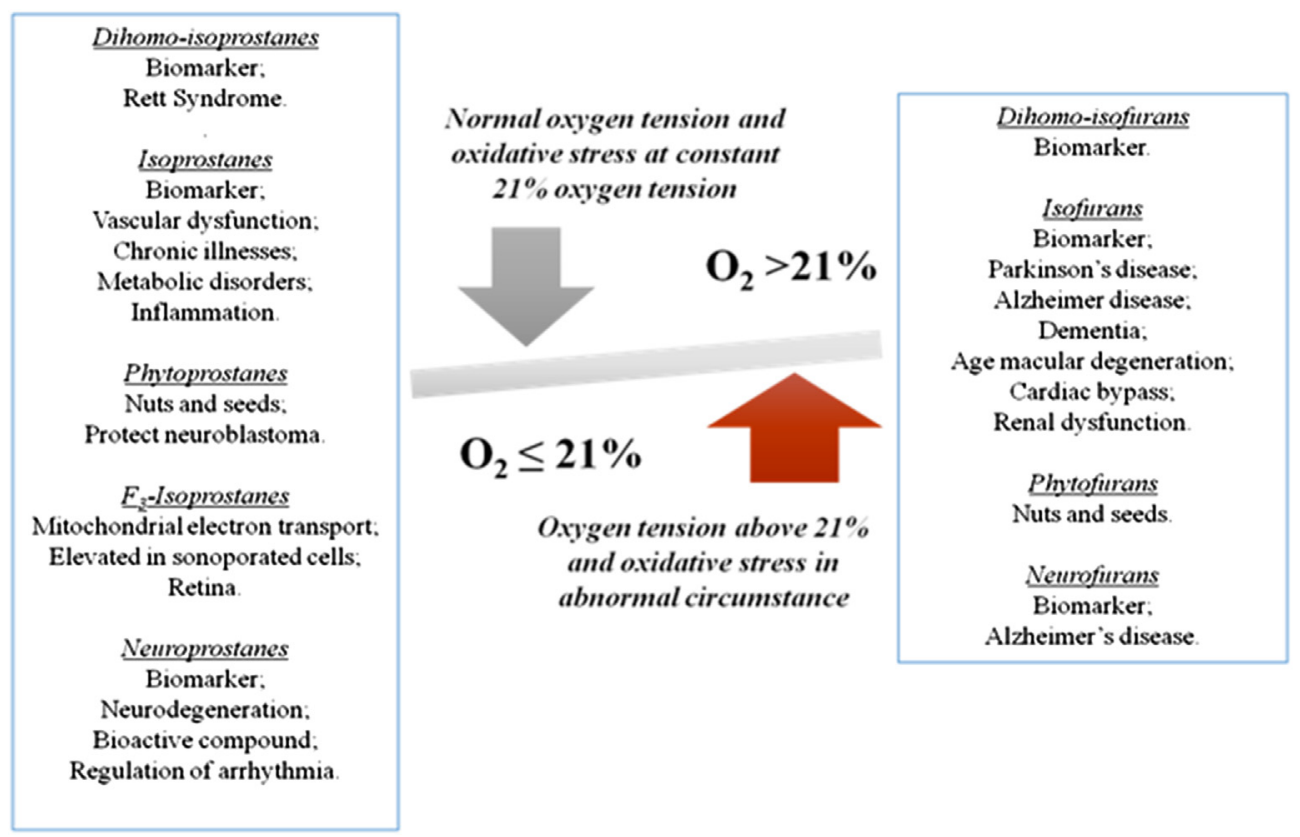

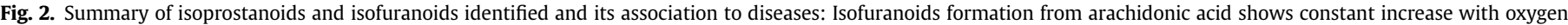

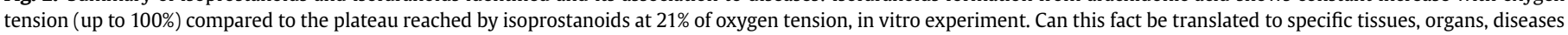
and pathologies for more accurate biomarkers of oxidative stress?. 
5.2.1.6. Lung. When determining isofuranoids in the biological systems, one area of interest is undoubtedly the lung since it is the main organ for oxygen delivery to the circulatory system. It was found that alveolar hemorrhage induces IsoFs formation in human bronchoalveolar lavage [62], and that plasma of patients undergoing lung transplant with primary graft dysfunction (PGD) had higher IsoFs level especially those receiving a smoker's lung compared to non-PGD and PGD [63]. Lung tissues of transgenic mice with low levels of tissue factor had higher IsoFs compared to the wild-type when exposed to inflammation such as lipopolysaccharide (LPS) [62] and mice with cytoplasmic domain mutation had higher IsoFs in the lung tissue compared to the controls [64]. Surprisingly, no reports were identified for dihomo-IsoFs and NeuroFs in relation to biological systems where oxygen concentrations were not intentionally induced as explained above.

5.2.1.7. Others. Aside from the function of vital organs, reports of isofuranoids levels were made in different systems. It was shown iron overload in mice did not alter IsoFs in the colon tissues compared to controls [65]. Moreover, the use of spinal anesthesia reduced plasma IsoFs whereas general anesthesia augmented IsoFs level in surgical procedure for leg ischemic-reperfusion compared to baseline [66]. High blood pressure showed an effect on IsoFs concentration, where maternal blood of pre-eclampsia showed higher IsoF levels compared to normal pregnancy [67]. It was also found plasma IsoFs may have potential role in the development of age macular degeneration (AMD) in adults [68] but, antioxidant supplementation was unable to reduce IsoFs in AMD patients [69]. Plasma IsoFs was found to have an association with visceral adiposity and smoking in Canadian Intuits but appears to decrease in plasma IsoFs with increased blood selenium concentration $[70,71]$. In a more recent study, IsoFs levels in red blood cells increased with storage time but interestingly a washing procedure of the red blood cells reduced the IsoFs level and were not further induced during storage [72]. Serum NeuroFs of infants of normal gestational period was determined lately [73] and PhytoFs in nuts and seed were measured, which showed some variable levels depending on the type [10].

\section{Conclusion}

It is clear from this report (Fig. 2) that isofuranoids are an important group of compounds in biological systems. They exist due to increased or dynamic change of oxygen tension in vivo in the vital organs, and the gauging of isofuranoids may be necessary in critical illnesses or surgical procedures, and monitoring neurodegenerative diseases for better management of the patients - an elevation or reduction by intervention could indicate the health status of the patients. Isofuranoids are a group of novel compounds which in the future could be promising oxidative stress biomarkers due to their stability and abundance especially in the brain and heart but may also have a biological role in particular ones from n-3 PUFA that needs to be studied explicitly.

\section{References}

1] F. Guéraud, M. Atalay, N. Bresgen, A Cipak, P.M. Eckl, L. Huc, I. Jouanin, W. Siems, K. Uchida, Chemistry and biochemistry of lipid peroxidation products, Free Radic. Res. 44 (2010) 1098-1124, http://dx.doi.org/10.3109/ 10715762.2010.498477.

[2] H. Yin, L. Xu, N.A. Porter, Free radical lipid peroxidation: mechanisms and analysis, Chem. Rev. 111 (2011) 5944-5972, http://dx.doi.org/10.1021/ cr200084z.

[3] C. Schneider, N.A. Porter, A.R. Brash, Routes to 4-Hydroxynonenal: fundamental issues in the mechanisms of lipid peroxidation, J. Biol. Chem. 283 (2008) 15539-15543, http://dx.doi.org/10.1074/jbc.R800001200.

[4] M. Morita, M. Tokita, The real radical generator other than main-product hydroperoxide in lipid autoxidation, Lipids 41 (2016) 91-95, http:// dx.doi.org/10.1007/s11745-006-5075-9.

[5] J.D. Morrow, K.E. Hill, R.F. Burk, T.M. Nammour, K.F. Badr, L.J. Roberts, A series of prostaglandin F2-like compounds are produced in vivo in humans by a noncyclooxygenase, free radical-catalyzed mechanism, Proc. Natl. Acad. Sci. 87 (1990) 9383-9387, http://dx.doi.org/10.1073/pnas.87.23.9383.

[6] U. Jahn, J.-M. Galano, T. Durand, Beyond Prostaglandins-Chemistry and biology of cyclic oxygenated metabolites formed by free-radical pathways from polyunsaturated fatty acids, Angew. Chem. Int. Ed. 47 (2008) 5894-5955, http://dx.doi.org/10.1002/anie.200705122.

[7] J.P. Fessel, N.A. Porter, K.P. Moore, J.R. Sheller, L.J. Roberts, Discovery of lipid peroxidation products formed in vivo with a substituted tetrahydrofuran ring (isofurans) that are favored by increased oxygen tension, Proc. Natl. Acad. Sci. 99 (2002) 16713-16718, http://dx.doi.org/10.1073/pnas.252649099.

[8] W.-L. Song, J.A. Lawson, D. Reilly, J. Rokach, C.-T. Chang, B. Giasson, G.A. FitzGerald, Neurofurans, novel indices of oxidant stress derived from docosahexaenoic acid, J. Biol. Chem. 283 (2008) 6-16, http://dx.doi.org/ 10.1074/jbc.M706124200.

[9] A. de La Torre, Y.Y. Lee, C. Oger, P.T. Sangild, T. Durand, J.C.-Y. Lee, J.-M. Galano, Synthesis, discovery, and quantitation of dihomo-isofurans: biomarkers for in vivo adrenic acid peroxidation, Angew. Chem. Int. Ed. 53 (2014) 6249-6252, http://dx.doi.org/10.1002/anie.201402440.

[10] C. Cuyamendous, K.S. Leung, T. Durand, J.C.-Y. Lee, C. Oger, J.-M. Galano, Synthesis and discovery of phytofurans: metabolites of $\alpha$-linolenic acid peroxidation, Chem. Commun. 51 (2015) 15696-15699, http://dx.doi.org/ 10.1039/C5CC05736A.

[11] D.F. Taber, J.P. Fessel, L.J. Roberts II, A nomenclature system for isofurans, Prostagl. Other Lipid Mediat. 73 (2004) 47-50, http://dx.doi.org/10.1016/ j.prostaglandins.2003.11.004.

[12] D.F. Taber, Y. Pan, X. Zhao, A flexible enantioselective synthesis of the isofurans, J. Org. Chem. 69 (2004) 7234-7240, http://dx.doi.org/10.1021/ jo048863o.

[13] D.F. Taber, Z. Zhang, Synthesis of the enediol isofurans, endogenous oxidation products of arachidonic acid, J. Org. Chem. 71 (2006) 926-933, http:// dx.doi.org/10.1021/jo051889a.

[14] D.F. Taber, P. Gu, R. Li, A divergent synthesis of the $\Delta 13-9$-isofurans, J. Org. Chem. 74 (2009) 5516-5522, http://dx.doi.org/10.1021/j0900767x.

[15] M. Valli, P. Bruno, D. Sbarbada, A. Porta, G. Vidari, G. Zanoni, Stereodivergent strategy for neurofuran synthesis via palladium-catalyzed asymmetric allylic

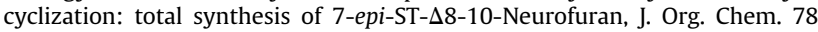
(2013) 5556-5567, http://dx.doi.org/10.1021/j04004647.

[16] A. de la Torre, Y.Y. Lee, A. Mazzoni, A. Guy, V. Bultel-Poncé, T. Durand, C. Oger J.C.-Y. Lee, J.-M. Galano, Total syntheses and in vivo quantitation of nove neurofuran and dihomo-isofuran derived from docosahexaenoic acid and adrenic acid, Chem. - Eur. J. 21 (2015) 2442-2446, http://dx.doi.org/10.1002/ chem.201405497.

[17] G.L. Milne, B. Gao, E.S. Terry, W.E. Zackert, S.C. Sanchez, Measurement of F2 isoprostanes and isofurans using gas chromatography-mass spectrometry, Free Radic. Biol. Med. 59 (2013) 36-44, http://dx.doi.org/10.1016/ j.freeradbiomed.2012.09.030.

[18] K.S. Leung, J.M. Galano, T. Durand, J.C.-Y. Lee, Current development in nonenzymatic lipid peroxidation products, isoprostanoids and isofuranoids, in novel biological samples, Free Radic. Res. 49 (2015) 816-826, http:// dx.doi.org/10.3109/10715762.2014.960867.

[19] C. Vigor, J. Bertrand-Michel, E. Pinot, C. Oger, J. Vercauteren, P. Le Faouder, J.M. Galano, J.C.-Y. Lee, T. Durand, Non-enzymatic lipid oxidation products in biological systems: assessment of the metabolites from polyunsaturated fatty acids, J. Chromatogr. B 964 (2014) 65-78, http://dx.doi.org/10.1016/ j.jchromb.2014.04.042

[20] Y.Y. Lee, C.K.C. Wong, C. Oger, T. Durand, J.-M. Galano, J.C.-Y. Lee, Prenatal exposure to the contaminant perfluorooctane sulfonate elevates lipid peroxidation during mouse fetal development but not in the pregnant dam, Free Radic. Res. 49 (2015) 1015-1025, http://dx.doi.org/10.3109/ 10715762.2015.1027199.

[21] G.S. Araujo, L.J.B.L. Matos, J.O. Fernandes, S.J.M. Cartaxo, L.R.B. Gonçalves, F.A.N. Fernandes, W.R.L. Farias, Extraction of lipids from microalgae by ultrasound application: prospection of the optimal extraction method, Ultrason. $\begin{array}{llll}\text { Sonochem. } 20 & \text { (2013) 95-98, http://dx.doi.org/10.1016 }\end{array}$ j.ultsonch.2012.07.027.

[22] J. Folch, M. Lees, G.H.S. Stanley, A simple method for the isolation and purification of total lipides from animal tissues, J. Biol. Chem. 226 (1957) 497-509.

[23] E.G. Bligh, W.J. Dyer, A rapid method of total lipid extraction and purification, can, J. Biochem. Physiol. 37 (1959) 911-917, http://dx.doi.org/10.1139/059099.

[24] E.P. Newberry, Y. Xie, S. Kennedy, X. Han, K.K. Buhman, J. Luo, R.W. Gross, N.O. Davidson, Decreased hepatic triglyceride accumulation and altered fatty acid uptake in mice with deletion of the liver fatty acid-binding protein gene, J. Biol. Chem. 278 (2003) 51664-51672, http://dx.doi.org/10.1074 jbc.M309377200.

[25] X.L. Guan, X. He, W.-Y. Ong, W.K. Yeo, G. Shui, M.R. Wenk, Non-targeted profiling of lipids during kainate-induced neuronal injury, FASEB J. 20 (2006) 1152-1161, http://dx.doi.org/10.1096/fj.05-5362com.

[26] J.X. Kang, J. Wang, A simplified method for analysis of polyunsaturated fatty acids, BMC Biochem. 6 (2005) 1-4, http://dx.doi.org/10.1186/1471-2091-6-5.

[27] M.R. Viant, B.G. Lyeth, M.G. Miller, R.F. Berman, An NMR metabolomic 
investigation of early metabolic disturbances following traumatic brain injury in a mammalian model, NMR Biomed. 18 (2005) 507-516, http://dx.doi.org/ $10.1002 / \mathrm{nbm} .980$

[28] J.A. Lawson, J. Rokach, G.A. FitzGerald, Isoprostanes: formation, analysis and use As indices of lipid peroxidation in vivo, J. Biol. Chem. 274 (1999) 24441-24444, http://dx.doi.org/10.1074/jbc.274.35.24441.

[29] J.D. Morrow, T.M. Harris, L. Jackson Roberts, Noncyclooxygenase oxidative formation of a series of novel prostaglandins: analytical ramifications for measurement of eicosanoids, Anal. Biochem. 184 (1990) 1-10, http:// dx.doi.org/10.1016/0003-2697(90)90002-Q.

[30] S. Medina, R. Domínguez-Perles, J.I. Gil, F. Ferreres, C. García-Viguera, J.M. Martínez-Sanz, A. Gil-Izquierdo, A ultra-pressure liquid chromatography triple quadrupole tandem mass spectrometry method for the analysis of 13 eicosanoids in human urine and quantitative 24 hour values in healthy volunteers in a controlled constant diet, Rapid Commun. Mass Spectrom. 26 (2012) 1249-1257, http://dx.doi.org/10.1002/rcm.6224.

[31] A. Della Corte, G. Chitarrini, I.M. Di Gangi, D. Masuero, E. Soini, F. Mattivi, U. Vrhovsek, A rapid LC-MS/MS method for quantitative profiling of fatty acids, sterols, glycerolipids, glycerophospholipids and sphingolipids in grapes, Talanta 140 (2015) 52-61, http://dx.doi.org/10.1016/j.talanta.2015.03.003.

[32] D.M.M. Luzia, N. Jorge, Fatty acids profile and alteration of lemon seeds extract (Citrus limon) added to soybean oil under thermoxidation, J. Food Sci. Technol. 50 (2011) 965-971, http://dx.doi.org/10.1007/s13197-011-0411-3.

[33] G. Caprioli, F. Giusti, R. Ballini, G. Sagratini, P. Vila-Donat, S. Vittori, D. Fiorini, Lipid nutritional value of legumes: evaluation of different extraction methods and determination of fatty acid composition, Food Chem. 192 (2016) 965-971, http://dx.doi.org/10.1016/j.foodchem.2015.07.102.

[34] A. Šućurović, N. Vukelić, L. Ignjatović, I. Brčeski, D. Jovanović, Physicalchemical characteristics and oxidative stability of oil obtained from lyophilized raspberry seed, Eur. J. Lipid Sci. Technol. 111 (2009) 1133-1141, http:// dx.doi.org/10.1002/ejlt.200900022.

[35] J. Jiao, Z.-G. Li, Q.-Y. Gai, X.-J. Li, F.-Y. Wei, Y.-J. Fu, W. Ma, Microwave-assisted aqueous enzymatic extraction of oil from pumpkin seeds and evaluation of its physicochemical properties, fatty acid compositions and antioxidant activities, Food Chem. 147 (2014) 17-24, http://dx.doi.org/10.1016/ j.foodchem.2013.09.079.

[36] M.P. Mansour, P. Shrestha, S. Belide, J.R. Petrie, P.D. Nichols, S.P. Singh, Characterization of oilseed lipids from "DHA-Producing camelina sativa": new transformed land plant containing long-chain Omega-3 oils, Nutrients 6 (2014) 776-789, http://dx.doi.org/10.3390/nu6020776.

[37] H. Yin, J.D. Morrow, N.A. Porter, Identification of a novel class of endoperoxides from arachidonate autoxidation, J. Biol. Chem. 279 (2004) 3766-3776, http://dx.doi.org/10.1074/jbc.M307137200.

[38] K. Lingappan, W. Jiang, L. Wang, G. Wang, X.I. Couroucli, B. Shivanna, S.E. Welty, R. Barrios, M.F. Khan, D.W. Nebert, L.J. Roberts, B. Moorthy, Mice deficient in the gene for cytochrome P450 (CYP)1A1 are more susceptible than wild-type to hyperoxic lung injury: evidence for protective role of CYP1A1 against oxidative stress, Toxicol. Sci. 141 (2014) 68-77, http:/ dx.doi.org/10.1093/toxsci/kfu106.

[39] L. Wang, K. Lingappan, W. Jiang, X.I. Couroucli, S.E. Welty, B. Shivanna R. Barrios, G. Wang, M. Firoze Khan, F.J. Gonzalez, L. Jackson Roberts, B. Moorthy, Disruption of cytochrome P4501A2 in mice leads to increased susceptibility to hyperoxic lung injury, Free Radic. Biol. Med. 82 (2015) 147-159, http://dx.doi.org/10.1016/j.freeradbiomed.2015.01.019.

[40] R.B. Cotton, H.W. Sundell, D.C. Zeldin, J.D. Morrow, L.J. Roberts, T.A. Hazinski, A.B. Law, S. Steele, Inhaled nitric oxide attenuates hyperoxic lung injury in lambs, Pediatr. Res. 59 (2006) 142-146, http://dx.doi.org/10.1203/ 01.pdr.0000191815.60293.cc.

[41] M. Vento, M. Moro, R. Escrig, L. Arruza, G. Villar, I. Izquierdo, L.J. Roberts, A. Arduini, J.J. Escobar, J. Sastre, M.A. Asensi, Preterm resuscitation with low oxygen causes less oxidative stress, inflammation, and chronic lung disease, Pediatrics 124 (2009) e439-e449, http://dx.doi.org/10.1542/peds.2009-0434.

[42] J. Kuligowski, M. Aguar, D. Rook, I. Lliso, I. Torres-Cuevas, J. Escobar, G. Quintás, M. Brugada, Á. Sánchez-Illana, J.B. van Goudoever, M. Vento, Urinary lipid peroxidation byproducts: are they relevant for predicting neonata morbidity in preterm infants? Antioxid. Redox Signal 23 (2015) 178-184 http://dx.doi.org/10.1089/ars.2015.6262.

[43] T.B. Corcoran, A.E. Barden, E. Mas, S. Grape, V. Koren, M. Phillips, L.J. Roberts II, T.A. Mori, Hemoglobin attenuates the effects of inspired oxygen on plasma isofurans in humans during upper-limb surgery, Free Radic. Biol. Med. 51 (2011) 1235-1239, http://dx.doi.org/10.1016/j.freeradbiomed.2011.06.026.

[44] E.R. Skinner, C. Watt, J.a.O. Besson, P.V. Best, Differences in the fatty acid composition of the grey and white matter of different regions of the brains of patients with Alzheimer's disease and control subjects, Brain 116 (1993) 717-725, http://dx.doi.org/10.1093/brain/116.3.717.

[45] Z.-C. Feng, E.L. Roberts Jr., T.J. Sick, M. Rosenthal, Depth profile of local oxygen tension and blood flow in rat cerebral cortex, white matter and hippocampus, Brain Res. 445 (1988) 280-288, http://dx.doi.org/10.1016/0006-8993(88 91190-0.

[46] R. Solberg, M. Longini, F. Proietti, P. Vezzosi, O.D. Saugstad, G. Buonocore Resuscitation with supplementary oxygen induces oxidative injury in the cerebral cortex, Free Radic. Biol. Med. 53 (2012) 1061-1067, http://dx.doi.org 10.1016/j.freeradbiomed.2012.07.022.

[47] G.W. Arendash, A.A. Cox, T. Mori, J.R. Cracchiolo, K.L. Hensley, L.J. Roberts, Oxygen treatment triggers cognitive impairment in Alzheimer's transgenic mice, NeuroReport 20 (2009) 1087-1092, http://dx.doi.org/10.1097/ WNR.0b013e32832e6459.

[48] M.L.S. Chung, J.-M. Galano, C. Oger, T. Durand, J.C.-Y. Lee, Hyperoxia elevates adrenic acid peroxidation in marine fish and is associated with reproductive pheromone mediators, Mar. Drugs 13 (2015) 2215-2232, http://dx.doi.org/ $10.3390 / \mathrm{md} 13042215$.

[49] J.P. Fessel, C. Hulette, S. Powell, L.J. Roberts, J. Zhang, Isofurans, but not F2isoprostanes, are increased in the substantia nigra of patients with Parkinson's disease and with dementia with Lewy body disease, J. Neurochem. 85 (2003) 645-650, http://dx.doi.org/10.1046/j.1471-4159.2003.01709.x.

[50] M. Patel, L.-P. Liang, H. Hou, B.B. Williams, M. Kmiec, H.M. Swartz, J.P. Fessel, L.J. Roberts, Seizure-induced formation of isofurans: novel products of lipid peroxidation whose formation is positively modulated by oxygen tension, J. Neurochem. 104 (2008) 264-270, http://dx.doi.org/10.1111/j.14714159.2007.04974.x.

[51] T.B. Corcoran, E. Mas, A.E. Barden, T. Durand, J.-M. Galano, L.J. Roberts, M. Phillips, K.M. Ho, T.A. Mori, Are isofurans and neuroprostanes increased after subarachnoid hemorrhage and traumatic brain injury? Antioxid. Redox Signal 15 (2011) 2663-2667, http://dx.doi.org/10.1089/ars.2011.4125.

[52] W. Balduini, S. Carloni, S. Perrone, S. Bertrando, M.L. Tataranno, S. Negro, F. Proietti, M. Longini, G. Buonocore, The use of melatonin in hypoxic-ischemic brain damage: an experimental study, J. Matern. Fetal Neonatal Med. 25 (2012) 119-124, http://dx.doi.org/10.3109/14767058.2012.663232.

[53] S.A. Simpson, H. Zaccagni, D.P. Bichell, K.G. Christian, B.A. Mettler, B.S. Donahue, L.J. Roberts, M. Pretorius, Acetaminophen attenuates lipid peroxidation in children undergoing cardiopulmonary bypass, Pediatr. Crit. Care Med. 15 (2014) 503-510, http://dx doi org/10.1097/PCC.0000000000000149.

[54] F.T. Billings IV, M.R. Petracek, L.J.R. Ii, M. Pretorius, Perioperative intravenous acetaminophen attenuates lipid peroxidation in adults undergoing cardiopulmonary bypass: a randomized clinical trial, PLoS One 10 (2015) e0117625, http://dx.doi.org/10.1371/journal.pone.0117625.

[55] J.H.Y. Wu, R. Marchioli, M.G. Silletta, S. Masson, F.W. Sellke, P. Libby, G.L. Milne, N.J. Brown, F. Lombardi, R.J. Damiano, J. Marsala, M. Rinaldi, A. Domenech, C. Simon, L. Tavazzi, D. Mozaffarian, Oxidative stress biomarkers and incidence of postoperative atrial fibrillation in the Omega-3 fatty acids for prevention of postoperative atrial fibrillation (OPERA) trial, J. Am. Heart Assoc. 4 (2015) e001886, http://dx.doi.org/10.1161/JAHA.115.001886.

[56] J. Roy, J.-Y. Le Guennec, J.-M. Galano, J. Thireau, V. Bultel-Poncé, M. Demion, C. Oger, J.C.-Y. Lee, T. Durand, Non-enzymatic cyclic oxygenated metabolites of omega-3 polyunsaturated fatty acid: bioactive drugs? Biochimie 120 (2016) 56-61, http://dx.doi.org/10.1016/j.biochi.2015.06.010.

[57] J. Himmelfarb, T.A. Ikizler, C. Ellis, P. Wu, A. Shintani, S. Dalal, M. Kaplan, M. Chonchol, R.M. Hakim, Provision of antioxidant therapy in hemodialysis (path): a randomized clinical trial, J. Am. Soc. Nephrol. 25 (2014) 623-633. http://dx.doi.org/10.1681/ASN.2013050545.

[58] M.B. Rivara, T.A. Ikizler, C.D. Ellis, R. Mehrotra, J. Himmelfarb, Association of plasma F2-isoprostanes and isofurans concentrations with erythropoiesisstimulating agent resistance in maintenance hemodialysis patients, BMC Nephrol. 16 (2015) 79, http://dx.doi.org/10.1186/s12882-015-0074-9.

[59] M.B. Rivara, R. Mehrotra, L. Linke, J. Ruzinski, T.A. Ikizler, J. Himmelfarb, A pilot randomized crossover trial assessing the safety and short-term effects of pomegranate supplementation in hemodialysis patients, J. Ren. Nutr. 25 (2015) 40-49, http://dx.doi.org/10.1053/j.jrn.2014.07.006.

[60] C.K. Yeung, F.T. Billings, A.J. Claessens, B. Roshanravan, L. Linke, M.B. Sundell, S. Ahmad, B. Shao, D.D. Shen, T.A. Ikizler, J. Himmelfarb, Coenzyme Q10 doseescalation study in hemodialysis patients: safety, tolerability, and effect on oxidative stress, BMC Nephrol. 16 (2015) 183, http://dx.doi.org/10.1186/ s12882-015-0178-2.

[61] L.B. Ware, J.P. Fessel, A.K. May, L.J. Roberts, Plasma biomarkers of oxidant stress and development of organ failure in severe sepsis, Shock 36 (2011) 12-17, http://dx.doi.org/10.1097/SHK.0b013e318217025a.

[62] J.A. Bastarache, S.C. Sebag, J.K. Clune, B.S. Grove, W.E. Lawson, D.R. Janz L.J. Roberts, R. Dworski, N. Mackman, L.B. Ware, Low levels of tissue factor lead to alveolar haemorrhage, potentiating murine acute lung injury and oxidative stress, Thorax 67 (2012) 1032-1039, http://dx.doi.org/10.1136/thoraxjnl2012-201781.

[63] J.M. Diamond, M.K. Porteous, L. Jackson Roberts, N. Wickersham, M. Rushefski, S.M. Kawut, R.J. Shah, E. Cantu, D.J. Lederer, S. Chatterjee, V.N. Lama, S. Bhorade, M. Crespo, J. McDyer, K. Wille, J. Orens, A. Weinacker, S. Arcasoy, P.D. Shah, D.S. Wilkes, C. Hage, S.M. Palmer, L. Snyder, C.S. Calfee, L.B. Ware, J.D. Christie, The relationship between plasma lipid peroxidation products and primary graft dysfunction after lung transplantation is modified by donor smoking and reperfusion hyperoxia, J. Heart Lung Transpl. 35 (2016) 500-507, http://dx.doi.org/10.1016/j.healun.2015.12.012.

[64] K.L. Lane, M. Talati, E. Austin, A.R. Hemnes, J.A. Johnson, J.P. Fessel, T. Blackwell, R.L. Mernaugh, L. Robinson, C. Fike, L.J. Roberts, J. West, Oxidative injury is a common consequence of BMPR2 mutations, Pulm. Circ. 1 (2011) 72-83, http://dx.doi.org/10.4103/2045-8932.78107.

[65] J.N.M. Ilsley, G.S. Belinsky, K. Guda, Q. Zhang, X. Huang, J.B. Blumberg, P.E. Milbury, L.J. R II, R.G. Stevens, D.W. Rosenberg, Dietary iron promotes azoxymethane-induced colon tumors in mice, Nutr. Cancer 49 (2004) 162-169, http://dx.doi.org/10.1207/s15327914nc4902_7.

[66] E. Mas, A.E. Barden, T.B. Corcoran, M. Phillips, L.J. Roberts II, T.A. Mori, Effects of spinal or general anesthesia on F2-isoprostanes and isofurans during ischemia/reperfusion of the leg in patients undergoing knee replacement 
surgery, Free Radic. Biol. Med. 50 (2011) 1171-1176, http://dx.doi.org/ 10.1016/j.freeradbiomed.2011.01.021.

[67] A.E. Barden, T.B. Corcoran, E. Mas, T. Durand, J.-M. Galano, L.J. Roberts, M. Paech, N.A. Muchatuta, M. Phillips, T.A. Mori, Is there a role for isofurans and neuroprostanes in pre-eclampsia and normal pregnancy? Antioxid. Redox Signal 16 (2011) 165-169, http://dx.doi.org/10.1089/ars.2011.4214.

[68] M.A. Brantley, M.P. Osborn, B.J. Sanders, K.A. Rezaei, P. Lu, C. Li, G.L. Milne, J. Cai, P. Sternberg, Plasma biomarkers of oxidative stress and genetic variants in age-related macular degeneration, Am. J. Ophthalmol. 153 (2012) 460-467, http://dx.doi.org/10.1016/j.ajo.2011.08.033 e1.

[69] M.A. Brantley, M.P. Osborn, B.J. Sanders, K.A. Rezaei, P. Lu, C. Li, G.L. Milne, J. Cai, P. Sternberg, The short-term effects of antioxidant and zinc supplements on oxidative stress biomarker levels in plasma: a pilot investigation, Am. J. Ophthalmol. 153 (2012) 1104-1109, http://dx.doi.org/10.1016/ j.ajo.2011.12.010 e2.

[70] D. Alkazemi, G.M. Egeland, L.J. R II, S. Kubow, Isoprostanes and isofurans as non-traditional risk factors for cardiovascular disease among Canadian Inuit, Free Radic. Res. 46 (2012) 1258-1266, http://dx.doi.org/10.3109/ 10715762.2012 .702900
[71] D. Alkazemi, G.M. Egeland, L.J. Roberts, H.M. Chan, S. Kubow, New insights regarding tissue $\mathrm{Se}$ and $\mathrm{Hg}$ interactions on oxidative stress from plasma IsoP and IsoF measures in the Canadian Inuit population, J. Lipid Res. 54 (2013) 1972-1979, http://dx.doi.org/10.1194/jlr.M033068.

[72] S.L. Spinelli, K.L. Lannan, A.E. Casey, A. Croasdell, T.M. Curran, K.F. Henrichs, S.J. Pollock, G.A. Milne, M.A. Refaai, C.W. Francis, R.P. Phipps, N. Blumberg Isoprostane and isofuran lipid mediators accumulate in stored red blood cells and influence platelet function in vitro, Transfus. Paris. 54 (2014) 1569-1579, http://dx.doi.org/10.1111/trf.12485.

[73] C. Cháfer-Pericás, L. Rahkonen, A. Sánchez-Illana, J. Kuligowski, I. TorresCuevas, M. Cernada, E. Cubells, A. Nuñez-Ramiro, S. Andersson, M. Vento J. Escobar, Ultra high performance liquid chromatography coupled to tandem mass spectrometry determination of lipid peroxidation biomarkers in newborn serum samples, Anal. Chim. Acta 886 (2015) 214-220, http:// dx.doi.org/10.1016/j.aca.2015.06.028.

[74] F.T. Billings IV, S.K. Ball, L.J. Roberts II, M. Pretorius, Postoperative acute kidney injury is associated with hemoglobinemia and an enhanced oxidative stress response, Free Radic. Biol. Med. 50 (2011) 1480-1487, http://dx.doi.org/ $10.1016 /$ j.freeradbiomed.2011.02.011. 